OPEN ACCESS

Edited by:

Quan Lu,

Chinese Academy of Forestry, China

Reviewed by:

Wei-Hua Tang,

Center for Excellence in Molecular Plant Sciences, Chinese Academy of

Sciences (CAS), China

Pedro Talhinhas,

University of Lisbon, Portugal

${ }^{*}$ Correspondence:

Zhongdong Yu

yuzhongdong001@nwsuaf.edu.cn

Zhimin Cao

zmcao@nwsuaf.edu.cn

Specialty section:

This article was submitted to Microbe and Virus Interactions with

Plants,

a section of the journal

Frontiers in Microbiology

Received: 08 January 2021 Accepted: 27 May 2021

Published: 25 June 2021

Citation:

Zheng W, Peng Z, Peng S, Yu Z and

Cao Z (2021) Multinuclei Occurred Under Cryopreservation and

Enhanced the Pathogenicity of Melampsora larici-populina. Front. Microbiol. 12:650902.

doi: 10.3389/fmicb.2021.650902

\section{Multinuclei Occurred Under Cryopreservation and Enhanced the Pathogenicity of Melampsora larici-populina}

\author{
Wei Zheng, Zijia Peng, Shaobing Peng, Zhongdong Yu* and Zhimin Cao* \\ College of Forestry, Northwest A\&F University, Yangling, China
}

Melampsora larici-populina is a macrocyclic rust, and the haploid stage with two nuclei and the diploid of mononuclear sequentially occur annually. During the preservation of dry urediniospores at $-80^{\circ} \mathrm{C}$, we found that one isolate, $\Delta T_{06}$, was different from the usual wild-type isolate $\mathrm{Ts}_{06}$ at $-20^{\circ} \mathrm{C}$ because it has mixed polykaryotic urediniospores. However, the other spores, including the 0, I, III, and IV stages of a life cycle, were the same as Ts06. After five generations of successive inoculation and harvest of urediniospores from the compatible host Populus purdomii, the isolate $\Delta \mathrm{Ts}_{06}$ steadily maintained more than $20 \%$ multiple nucleus spores. To test the pathogenesis variation of $\Delta T_{06}$, an assay of host poplars was applied to evaluate the differences between $\Delta T_{06}$ and $T_{06}$. After $\Delta T_{s_{06}}$ and $T_{06}$ inoculation, leaves of $P$. purdomii were used to detect the expression of small secreted proteins (SSPS) and fungal biomasses using quantitative real-time PCR (qRT-PCR) and trypan blue staining. $\Delta$ Ts $_{06}$ displayed stronger expression of five SSPs and had a shorter latent period, a higher density of uredinia, and higher DNA mass. A transcriptomic comparison between $\Delta \mathrm{Ts}_{06}$ and $\mathrm{Ts}_{06}$ revealed that 3,224 were differentially expressed genes (DEGs), 55 of which were related to reactive oxygen species metabolism, the Mitogen-activated protein kinase (MAPK) signaling pathway, and the meiosis pathway. Ten genes in the mitotic and meiotic pathways and another two genes associated with the "response to DNA damage stimulus" all had an upward expression, which were detected by qRT-PCR in $\triangle T_{s_{06}}$ during cryopreservation. Gas chromatography-mass spectrometry (GC-MS) confirmed that the amounts of hexadecanoic acid and octadecadienoic acid were much more in $\Delta T_{06}$ than in Ts06. In addition, using spectrophotometry, hydrogen peroxide $\left(\mathrm{H}_{2} \mathrm{O}_{2}\right)$ was also present in greater quantities in $\Delta \mathrm{Ts}_{06}$ compared with those found in Ts06. Increased fatty acids metabolism could prevent damage to urediniospores in super-low temperatures, but oxidant species that involved $\mathrm{H}_{2} \mathrm{O}_{2}$ may destroy tube proteins of mitosis and meiosis, which could cause abnormal nuclear division and lead to multinucleation, which has a different genotype. Therefore, the multinuclear isolate is different from the wild-type isolate in terms of phenotype and genotype; this multinucleation phenomenon in urediniospores improves the pathogenesis and environmental fitness of $M$. larici-populina.

Keywords: Melampsora larici-populina, multinucleation, transcriptomics, pathogenicity variation, adaptation, cryopreservation 


\section{INTRODUCTION}

Melampsora larici-populina Kleb., an obligate biotrophic parasite, has caused heavy rust infections with disastrous consequences for the poplar industry (Steenackers et al., 1996; Newcombe, 1998). It is a macrocyclic rust that completes its life cycle on larch and poplar (Figure 1) and involves five types of spores: pycniospores (monokaryon), aeciospores (dikaryon), urediniospores (dikaryon), teliospores (diploid monokaryon), and basidiospores (monokaryon) (Lorrain et al., 2019). However, multinucleation has been observed in several rust fungi, including $M$. larici-populina, and the life cycle shows obvious diversity. For example, Uromyces vignae Barclay has a macrocyclic life cycle, but it completes the life cycle on a single species host, during which basidiospores develop into monopyrenous hyphae and urediniospores consist of eight or 16 nuclei. After the differentiation of haustorial mother cells, intercellular hyphae develop four to 12 nuclei, which gradually decrease over time. Primary haustorial mother cells have four or five nuclei but are rarely dikaryon (Heath et al., 1996). Septate hyphae of Puccinia sorghi were formed after the mitosis of one or two nuclei; hence, primary hyphae are trinucleate (Savile, 1939). The primary hyphae of $P$. malvacearum are divided into one anucleate cell and one binucleate cell, and the latter is divided into two monocytes by one septum (Allen, 1935). Multinucleation is very common during the infection process of $P$. striiformis f. sp. tritici, especially in germ tubes, intercellular hyphae, haustorial mother cells, and haustorial cells (Little and Manners, 1969; Kang et al., 2015). Germ tubes of the urediniospores of $M$. larici-populina fuse on the surface of the poplar leaves and form multinucleate cells (Yu et al., 2009), but the vegetative hyphae typically become dikaryotic hyphae when the multinucleate cells develop into infected hyphae. The dikaryon hyphae do not grow with clamp connections, and a sister nucleus in vegetative hyphae is copied in a "half-reserve" manner, with one disappearing or becoming retained and the other flowing into a new cell and remaining as a dikaryon through mitosis ( $\mathrm{Yu}$ et al., 2017). When the basidiospores regerminate, binucleate secondary basidiospores are formed and can more easily infect the host (Yu et al., 2009).

Multinucleation can occur in the following ways: 1) germ tube fusion or hyphal fusion. Since 1989, fusant formation and fusion phenomena of germ tubes, appressoria, substomatal cavities, or hyphae have been observed in a variety of Puccinia species (Park and Wellings, 2012). Wilcoxon et al. (1958) discovered that the cytoplasm in germ tubes moved to the fusant, which had two to four nuclei. Taylor (1976) discovered that somatic recombination could produce a new race by albino strains of $P$. striiformis $\mathrm{f}$. sp. tritici. The proportions of tri- and tetra-nucleate germ tubes in the new race were significantly higher than those in the original strains. 2) Nucleus mutation: factors for nuclear mutation include ion radiation, chemical action, temperature changes, and $\mathrm{pH}$ changes (Huang et al., 2009; Anderson et al., 2015). They can cause nuclear DNA damage and subsequently lead to abnormal mitosis and multinucleation (Maheshwari, 2005).

Multinucleation often leads to different cytological and biological traits, causing special life cycles and diverse environmental fitness, especially for macrocyclic rust fungi, whose haploid and diploid stages are strictly defined in their life cycle. Moreover, multinucleation can cause changes in phenotypes, including the latent period, uredinium density, uredinium diameter, and uredinium height in a range of hosts (Chandrasbekar and Heather, 1980). In the interaction between plants and pathogens, avirulence proteins are generally thought to be pathogenicity effectors that have positive roles. Some effectors are targeted to the host nucleus and may act as transcription factors (Lahaye and Bonas, 2001), whereas others are proteases that cleave specific cytoplasmic host proteins (Orth et al., 2000). Hacquard et al. (2012) found that parts of small secreted proteins (SSPs) in M. larici-populina are homologous to avirulence genes of M. lini. For example, Mlp124272 and Mlp124256 are homologous to AvrP4; Mlp37347 is homologous to AvrL567; Mlp124530 is homologous to AvrP123; and Mlp123932 is homologous to haustorially expressed secreted protein (HESP) HESP-327. Furthermore, specific labeling of Mlp37347 and Mlp123932 was detected at the periphery of haustoria. Mlp124272, Mlp124256, and Mlp124530 showed very strong labeling in the development of uredinia (Hacquard et al., 2012). SSPs that involved avirulence effectors were those important molecular associated with changing phenotypes. RNA sequencing (RNA-Seq), also known as transcriptome sequencing, is universally employed to analyze differential gene expression through deep sequencing during pathogen-host interactions (Wang et al., 2009). Over the past decade, RNA-Seq has gradually become an indispensable tool for analyzing differential gene expression (Stark et al., 2019). For example, Hacquard et al. (2013) revealed the karyogamy and meiosis processes before and after overwintering through transcriptome analysis of $M$. larici-populina telia.

Rust fungi are obligate parasites; hence, artificial culture technology is difficult to implement in biological research, including sporulation, mating, and subcellular structure under artificial synthesis media. Therefore, their spore propagulum is usually kept for research in dry conditions at $-20^{\circ} \mathrm{C}$ for 1 year or at $-80^{\circ} \mathrm{C}$ for more than 1 year. However, we found that multinucleation occurred in urediniospores of strain $\mathrm{Ts}_{06}$ stored at $-80^{\circ} \mathrm{C}$, and we obtained a mutant strain $\left(\Delta \mathrm{Ts}_{06}\right)$ after purification and separation. The mutant strain, $\Delta \mathrm{Ts}_{06}$, was significantly different from $\mathrm{Ts}_{06}$ in host selection, pathogenicity, and other biological characteristics. Therefore, to investigate the genetic stability of mutated strains and the mechanism of multinucleation occurrence, we analyzed the stability of the life cycle of $\Delta \mathrm{Ts}_{06}$ using artificial inoculation on the compatible host $P$. purdomii for consecutive subcultures. The phenotype responses on different hosts and the expression of SSPs under real-time fluorescence quantitative analysis were used to determine the differences in pathogenicity between $\Delta \mathrm{Ts}_{06}$ and $\mathrm{Ts}_{06}$. The molecular mechanism of urediniospore multinucleation was explored using transcriptomics combined with real-time fluorescence quantitative PCR on nuclear division-related genes. The research results are of crucial theoretical significance in understanding the life history, pathogenicity variation, mechanism and environmental adaptability of such obligate parasites. 


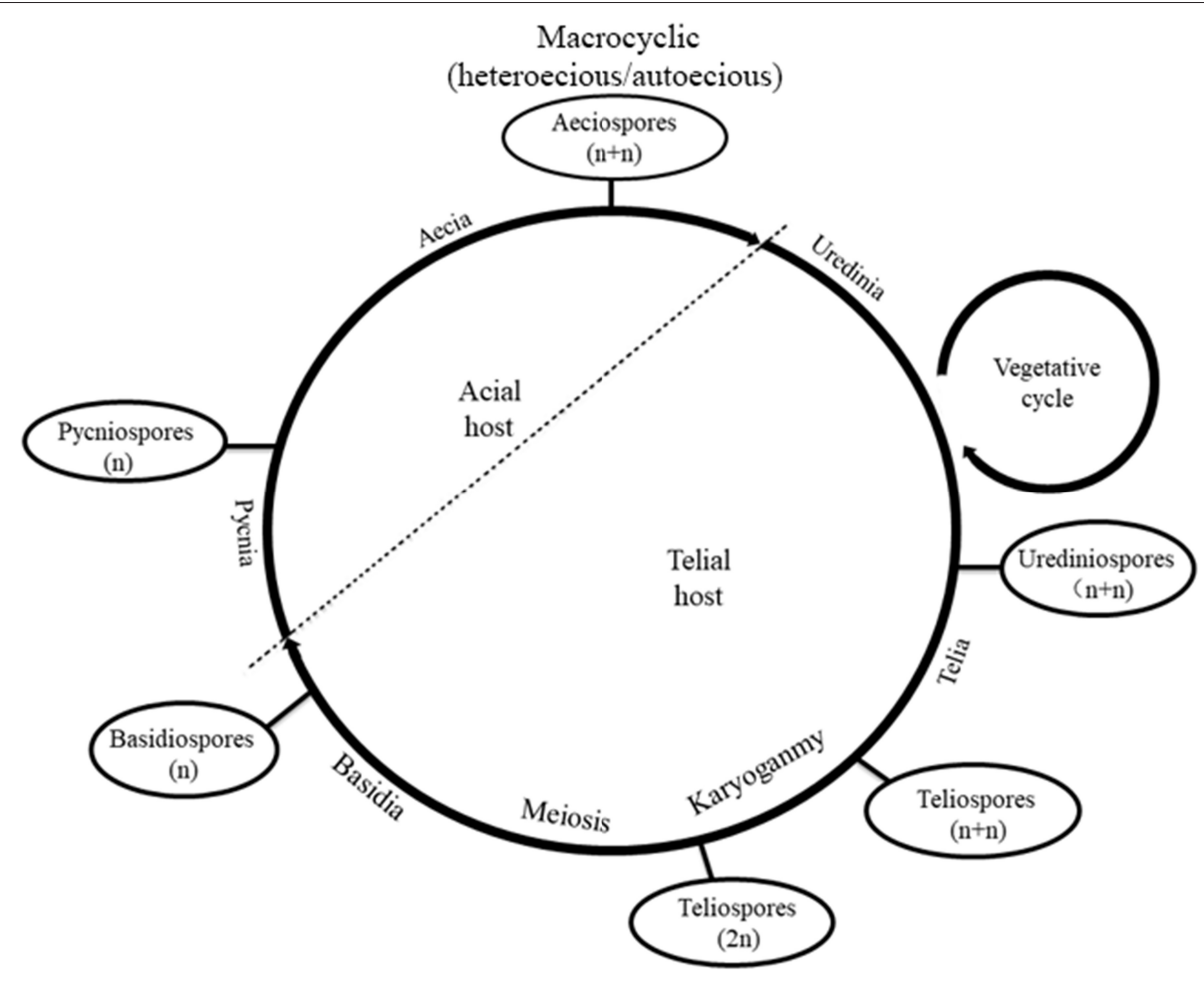

FIGURE 1 | Life cycle of Melampsora larici-populina.

\section{MATERIALS AND METHODS}

\section{Materials}

\section{Strains}

Mutant strain $\mathrm{Ts}_{06}\left(\Delta \mathrm{Ts}_{06}\right)$ at ultralow temperature $\left(-80^{\circ} \mathrm{C}\right)$ and unmutated dikaryon strain $\mathrm{Ts}_{06}$. $P$. purdomii is the natural host of M. larici-populina collected in Qinling Mt., China. P. purdomii, the other four hosts (Table 1), and the aecial host of Chinese larch (Larix principis-rupprechtii Mayr.) were planted in greenhouse conditions at $25^{\circ} \mathrm{C}, 70 \%-80 \%$ relative humidity $(\mathrm{RH})$, and $16 \mathrm{~h}$ photoperiod (2,500 lux at leaf level) for in planta experiments. They are healthy 1 -year-old seedlings.

\section{Nuclear Observation of the $\Delta \mathrm{Ts}_{06}$ Life Cycle}

Nuclei were stained with DAPI (Sigma Chemical Company, St. Louis, MO, USA) and were dated under fluorescence microscope (Leica DM4000B, Leica Microsystems GmbH, Wetzlar, Germany). Urediniospores of $\Delta \mathrm{Ts}_{06}$ were prepared in spore suspensions at a concentration of $0.01 \mathrm{~g} / \mathrm{ml}$ and were smeared on a $2 \%$ water agar medium for germination and on abaxial leaves of $P$. purdomii for inoculation as described in Zheng et al. (2019). Histological observation of intercellular hyphae, haustorial mother cells, and haustoria was implemented using a Hitachi HT-7700 TEM (Hitachi, Tokyo, Japan) (Kang and Buchenauer, 2000). Urediniospores of $\Delta \mathrm{Ts}_{06}$ were continuously subcultured on $P$. purdomii and harvested five times, and the proportion of polykaryotic urediniospores was counted in each harvest. Meanwhile, P. purdomii of 10 days post inoculation (dpi) were transferred to a chamber to induce teliospores at $4^{\circ} \mathrm{C}$, and basidiospores developed according to the protocol outlined in $\mathrm{Yu}$ et al. (2009). Thereafter, basidiospores were inoculated on the needles of a larch, and then they were moved to the greenhouse until spermatia developed (Pernaci et al., 2014). The basidia, basidiospores, spermatia, and aeciospores were stained using DAPI and were observed and photographed using a Leica DM4000B microscope. The strain $\mathrm{Ts}_{06}$, used as a control, was observed simultaneously with $\Delta \mathrm{Ts}_{06}$.

\section{Determination of Pathogenicity and Fungal Biomass}

$P$. purdomii, $P$. deltoides, $P$. szechuanica, $P . \times$ euramericana $\mathrm{cv}$. Polska $15 \mathrm{~A}$, and $P . \times$ euramericana $\mathrm{cv}$. Robusta were selected for pathogenesis tests (Pinon et al., 1987; Pinon and Frey, 1997). $\Delta \mathrm{Ts}_{06}$ and $\mathrm{Ts}_{06}$ at $0.01 \mathrm{~g} / \mathrm{ml}$ of urediniospores were inoculated on each host using three biological replicates. The latent period (days), uredinia density (number per $\mathrm{cm}^{2}$ ), uredinia diameter $(\mathrm{mm})$, and uredinia height $(\mathrm{mm})$ were recorded after inoculation. To measure density, a $1-\mathrm{cm}^{2}$ piece of paper was placed on the back of the leaves. The number of uredinia in at least 5$\mathrm{cm}^{2}$ of paper per leaf was randomly counted to calculate the average density value. The uredinium diameter and height were observed and measured using an anatomical lens. All analyses were performed with SPSS 22.0 (Chicago, Chicago, IL, USA). The means of the densities were determined using Duncan's multiple range test at $p<0.05$. Simultaneously, leaves of $P$. purdomii were 
TABLE 1 | Comparison of pathogenicity of $\Delta \mathrm{Ts}_{06}$ and $\mathrm{Ts}_{06}$.

\begin{tabular}{|c|c|c|c|c|c|c|}
\hline & & \multicolumn{5}{|c|}{ Host } \\
\hline \multirow{2}{*}{$\begin{array}{l}\text { Latent } \\
\text { period/days }\end{array}$} & $\Delta \mathrm{Ts}_{06}$ & 5 & / & 7 & $6 \sim 7$ & 7 \\
\hline & $\mathrm{Ts}_{06}$ & 6 & / & 7 8 & 7 & $7 \sim 8$ \\
\hline \multirow{2}{*}{$\begin{array}{l}\text { Sorus } \\
\text { density } / \mathrm{cm}^{-2}\end{array}$} & $\Delta \mathrm{Ts}_{06}$ & $79.0 \pm 2.60^{a}$ & $\mathrm{O}^{\mathrm{a}}$ & $13.0 \pm 1.29^{a}$ & $52.0 \pm 2.29^{a}$ & $6.0 \pm 1.49^{a}$ \\
\hline & $\mathrm{Ts}_{06}$ & $63.0 \pm 1.91^{b}$ & $0^{a}$ & $5.0 \pm 0.93^{b}$ & $41.0 \pm 1.78^{b}$ & $3.0 \pm 0.55^{b}$ \\
\hline \multirow{2}{*}{$\begin{array}{l}\text { Sorus } \\
\text { height/mm }\end{array}$} & $\Delta \mathrm{Ts}_{06}$ & $0.31 \pm 0.03^{a}$ & / & $0.18 \pm 0.04^{a}$ & $0.25 \pm 0.02^{\mathrm{a}}$ & $0.23 \pm 0.02^{a}$ \\
\hline & $\mathrm{Ts}_{06}$ & $0.34 \pm 0.03^{a}$ & / & $0.19 \pm 0.02^{a}$ & $0.28 \pm 0.02^{\mathrm{a}}$ & $0.25 \pm 0.02^{\mathrm{a}}$ \\
\hline
\end{tabular}

Significance at $p<0.05$ is indicated by different letters in the table (Duncan's multiple range test).

collected using a kit (Cat\# BSC65S1B; BioFlux, San Francisco, CA, USA) at $0,12,24,48,96$, and $168 \mathrm{~h}$ post inoculation (hpi) to obtain qualified RNA. The iScript ${ }^{\mathrm{TM}} \mathrm{cDNA}$ kit was used for cDNA synthesis (Cat\# 1708891; Bio-Rad Laboratories, Hercules, CA, USA). The SsoFast ${ }^{\mathrm{TM}}$ EvaGreen ${ }^{\circledR}$ Supermix kit was used for qPCR (Cat\# 172-5201; Bio-Rad) with SSP primers, as shown in Table 2 (Hacquard et al., 2011; Vieira et al., 2011). Alpha-tubulin $(a T U B)$ and elongation factor-1-alpha (ELF1a) of M. laricipopulina were selected as reference genes, and amplification reaction conditions were the same as in Ye et al. (2018). The DNA of leaves during infection was extracted using a DNA extraction kit (Tiangen, Beijing, China). A species-specific $\mathrm{ITS}_{1-\mathrm{F}} / \mathrm{ITS}_{4-\mathrm{B}}$ of M. larici-populina was also employed to quantify the fungal biomass (Boyle et al., 2005). The gene expression was calculated using the $2^{-\Delta \Delta \mathrm{Ct}}$ method of the dissolution curve (Livak and Schmittgen, 2001) in the quantitative fluorescent amplification. The two-tailed $t$-test was applied using the software GraphPad Prism 5 to check the qRT-PCR data. The fungal biomass in 168 hpi leaves of $P$. purdomii was also detected using trypan blue staining methods as outlined in Dang et al. (2013); these stained leaves were transferred into a chloral hydrate solution ( $2.5 \mathrm{~g}$ of chloral hydrate dissolved in $1 \mathrm{ml}$ of distilled water) and boiled for $20 \mathrm{~min}$ to destain. The numbers and sizes of the developed fungal colonies of $\Delta \mathrm{Ts}_{06}$ and $\mathrm{Ts}_{06}$ in the tissues were compared.

\section{Transcriptome Sequencing and Differential Gene Expression Analysis}

$\mathrm{Ts}_{06}$ urediniospores previously stored at $-20^{\circ} \mathrm{C}$ were used to reproduce fresh urediniospores, which were marked CK20. $\Delta \mathrm{Ts}_{06}$ urediniospores stored at $-20^{\circ} \mathrm{C}$ for 1 year were marked One20, and those stored for 2 years were marked Two20. $\mathrm{Ts}_{06}$ urediniospores previously stored at $-80^{\circ} \mathrm{C}$ were used to reproduce fresh urediniospores, which were marked CK80. $\Delta \mathrm{Ts}_{06}$ urediniospores stored at $-80^{\circ} \mathrm{C}$ for 1 year were marked One80, and those stored for 2 years were marked Two80. Two biological replicates were used for transcriptome analysis. Total RNA was extracted from $5 \mathrm{mg}$ of urediniospores at the corresponding temperature and sequenced using BGISEQ500 by Hua Da Biotechnological Co., Ltd. (Beijing, China). Clean reads were compared with the genome sequence of $M$. larici-populina (JGI; http://genome.jgi-psf.org/Mellp1/Mellp1. home.html) using hierarchical indexing for spliced alignment of transcripts (HISAT) software (Kim et al., 2015). The gene expression level of each sample was calculated using RSEM (RNA-Seq by Expectation Maximization), and the genes with a false discovery rate $(F D R) \leq 0.001$ and an absolute value of the $\log 2$-fold change $\geq 1$ were considered as differentially expressed genes (DEGs) (Li and Dewey, 2011). A Venn diagram, created using TBtools software, was used to illustrate the number of DEGs at the intersection of CK20 vs. One20, CK20 vs. Two20, CK80 vs. One80, and CK80 vs. Two80 (Chen et al., 2020). The expression clustering analysis of the intersecting DEGs was conducted using the heat map function in $\mathrm{R}$ software. According to the annotation results of Gene Ontology (GO) and the Kyoto Encyclopedia of Genes and Genomes (KEGG), an enrichment analysis was conducted on the intersecting DEGs using the phyper function in $\mathrm{R}$ software, and the $p$ value was calculated and adjusted using FDR. Typically, functions with $\mathrm{Q}$ values $\leq 0.05$ are regarded as significantly enriched. The intersecting DEGs were compared with the STRING database using DIAMOND (http://www.diamondsearch.org), and the relationship between interacting genes was obtained using homology and known proteins.

\section{Validation of Differentially Expressed Gene Expressions Using qRT-PCR}

To verify the transcriptome data, genes differentially expressed in the mitotic and meiotic pathways and genes associated with "response to DNA damage stimuli" were selected for qRT-PCR verification. The alpha-tubulin $(a T U B)$ and elongation factor1-alpha (ELF1a) of M. larici-populina were used as reference genes (Hacquard et al., 2011). Primers were designed by software Beacon Designer 7.9 (Premier Biosoft International, USA, Table 3) according to the transcripts obtained in this experiment. The amplification reaction conditions followed Ye 
TABLE 2 | Primer sequences of small secreted proteins and the referred genes.

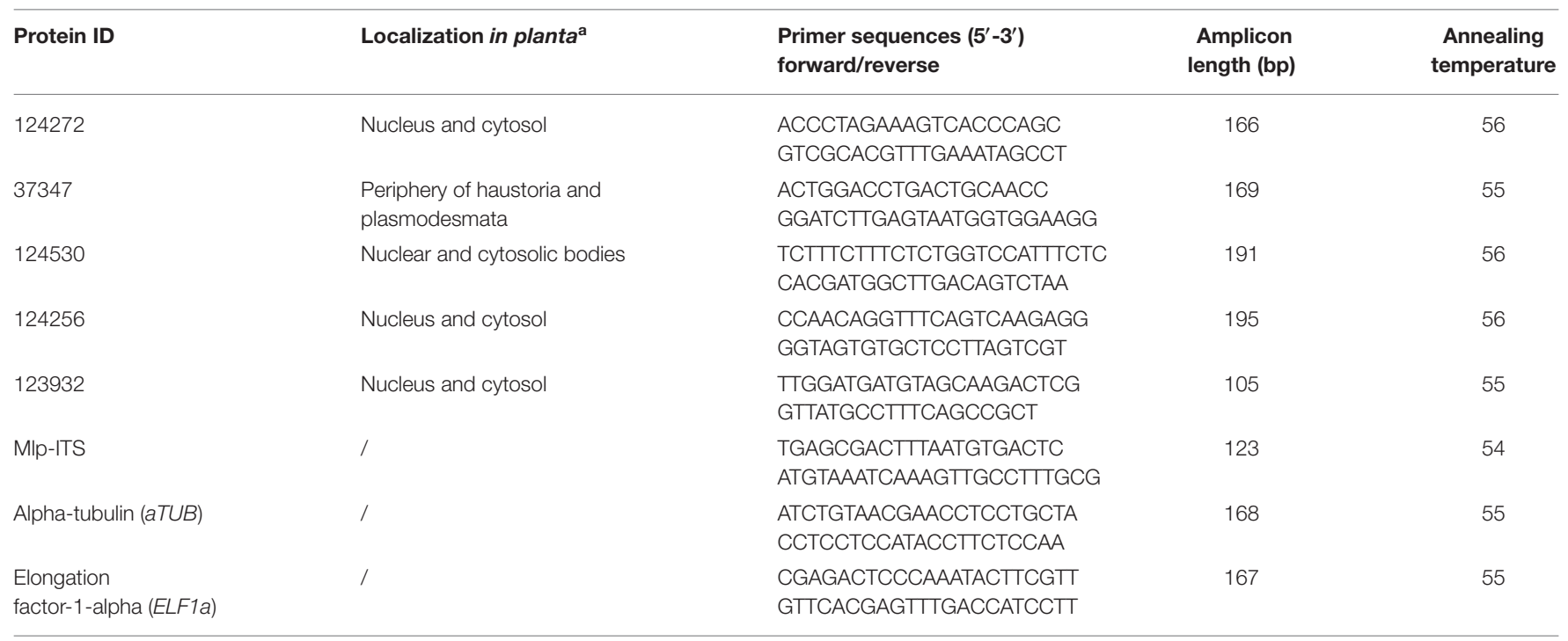

${ }^{a}$ As described in Petre et al. (2015).

TABLE 3 | Primer sequences of candidate genes and the referred genes.

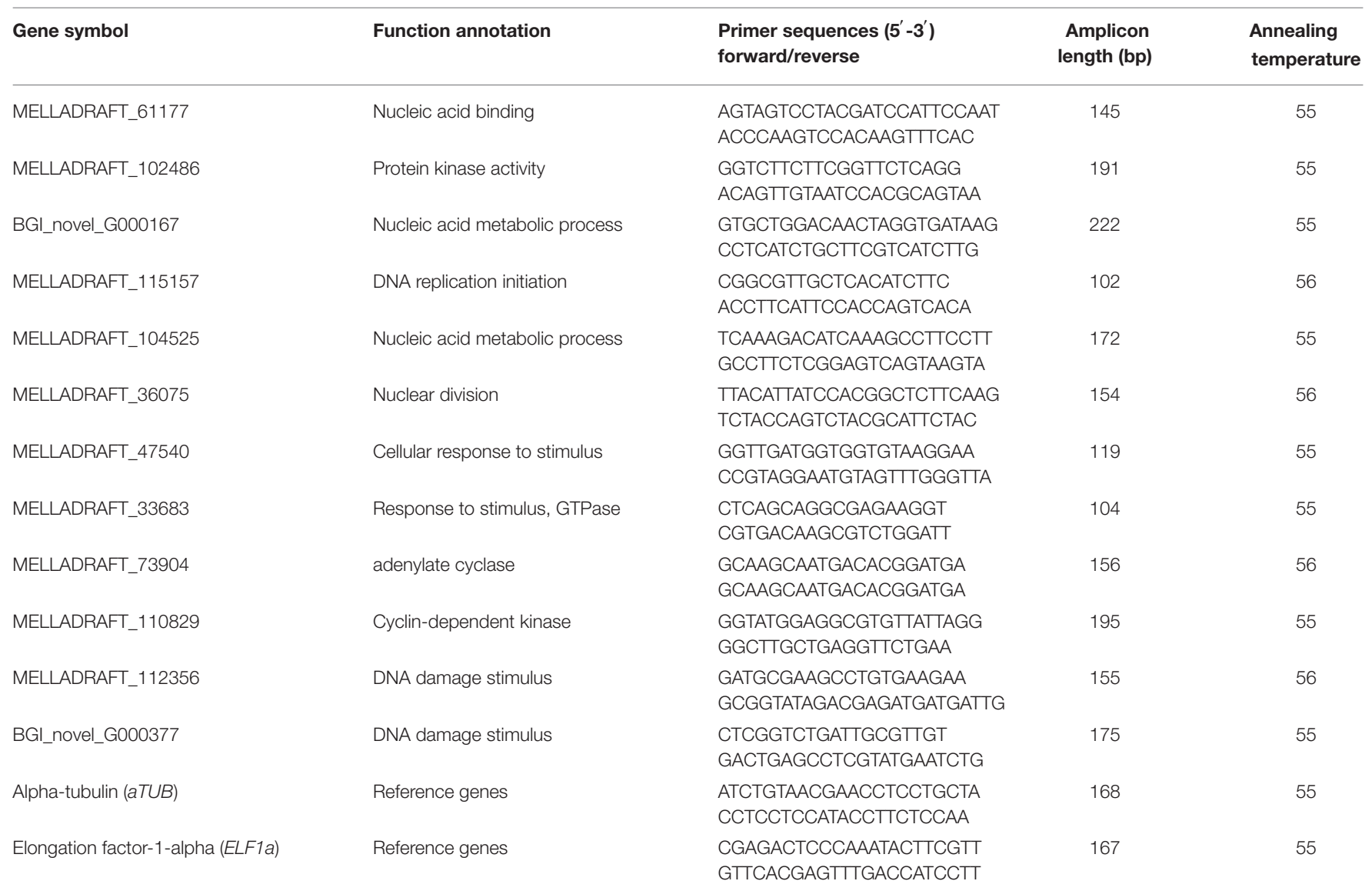


et al. (2018), and gene expressions were calculated using the $2^{-\Delta \Delta \mathrm{Ct}}$ method (Livak and Schmittgen, 2001).

\section{Hydrogen Peroxide and Fatty Acid Detection}

Six samples (CK20, One20, Two20, CK80, One80, and Two80) of $0.05 \mathrm{~g}$ of urediniospores were used to detect concentrations of $\mathrm{H}_{2} \mathrm{O}_{2}$ according to the protocol of Kit YX-W-A400 (Sinobest Bio Co., Ltd., Shanghai, China). In addition, $0.1 \mathrm{~g}$ of urediniospores from Two80 and $0.1 \mathrm{~g}$ from CK80 were selected to detect fatty acids using gas chromatography-mass spectrometry (GC-MS, QP2010; Shimadzu Corp., Kyoto, Japan) (Zhao et al., 2020). Each sample was biologically repeated three times, and the means of each detection were determined using Duncan's multiple range test (software SPSS 22.0, Chicago, IL, USA).

\section{Detection of Genotype Variation Between $\Delta \mathrm{Ts}_{06}$ and $\mathrm{Ts}_{06}$}

We used the method in Virtudazo et al. (2001) to extract DNA from $\Delta \mathrm{Ts}_{06}$ and $\mathrm{Ts}_{06}$ urediniospores. Random amplified microsatellites (RAMs) were applied to screen for differences in whole genomic DNA between $\Delta \mathrm{Ts}_{06}$ and $\mathrm{Ts}_{06}$. The RAM primers were designed (Supplementary Table 1), and the PCR was carried out following the procedure outlined in Hantula et al. (1996). Amplification products were separated using electrophoresis in $2.0 \%$ agarose gels, and the DNA profiles of $\Delta \mathrm{Ts}_{06}$ and $\mathrm{Ts}_{06}$ were carefully compared. The occurrence of different DNA profiles manifests a different genotype at the allelic gene.

\section{RESULTS}

\section{Nuclei in the Life Cycle of $\Delta \mathrm{Ts}_{06}$}

During the uredial stage, both $\Delta \mathrm{Ts}_{06}$ urediniospores and their germ tubes contain four to six nuclei (Figures 2A-C). After successfully infecting $P$. purdomii, within 1 day, haustorial mother cells and haustoria developed and had two to three nuclei (Figures 2J,K). In addition, intercellular hyphae developed in the mesophyll tissue, and each somatic cell had three to five nuclei (Figure 2L). A few intercellular hyphae were fused together, and the nucleus flow along with them (Figure 2M). After approximately $6 \mathrm{dpi}$, intercellular hyphae finally developed into urediniospores that had four to five nuclei (Figures $2 \mathrm{~N}, \mathbf{O}$ ), which took on about $20 \%$ of total fresh urediniospores during each of the five consecutive generations. However, $\mathrm{Ts}_{06}$ urediniospores, germ tubes, intercellular hyphae, haustorial mother cells, and haustoria are all typically dikaryotic (Supplementary Figure 1). During the telial stage, unmatured teliospores are initially binucleate (Figure 2D), and they fused into one nucleus after maturity (Figure 2E). After one time of meiosis, the basidium from the germination of teliospores is divided into four cells by three septa, and each cell has a nucleus (Figure 2F). The basidiospores are produced on the stigma of the promycelium. As the tip expands, one nucleus flows into it, and mitosis occurs. Finally, basidiospores with two nuclei are formed (Figure 2G). The basidiospores infect needles of Larix and produce spermogonia and mononuclear spermatia on the adaxial

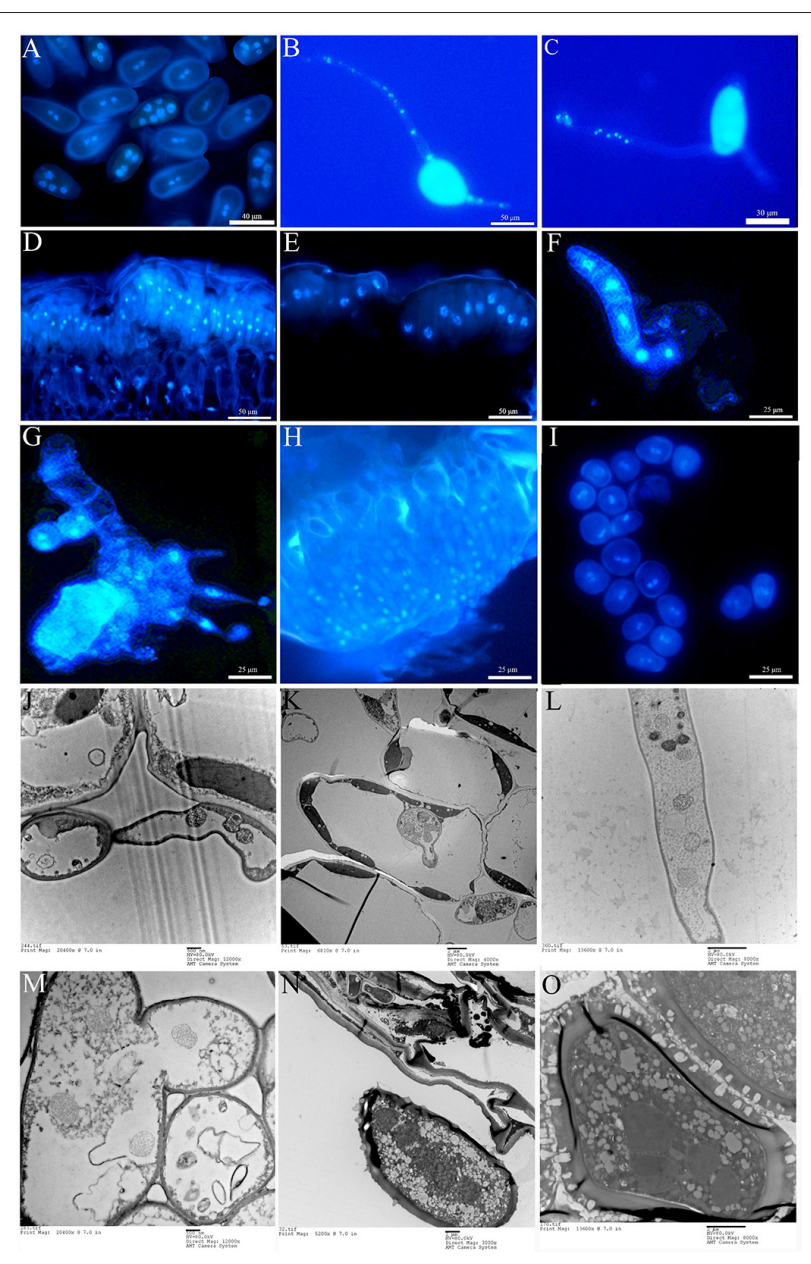

FIGURE 2 | Nuclear observation of the life cycle of $\Delta T_{06}$ in the. (A) DAPI staining of urediniospores. (B,C) Polykaryon germ tube. (D) Initial teliospores. (E) Mature teliospores. (F) Basidium. (G) Basidiospores. (H) Spermatia. (I) Aeciospores. (J) Polynuclear haustorial mother cell. (K) Polynucleated haustoria. (L) Polynucleated intercellular hyphae. (M) Fusing intercellular

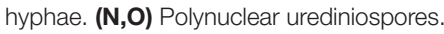

surface of the needles (Figure $\mathbf{2 H}$ ). A week after the development of spermogonia, aecidium and binuclear aeciospores appeared on the abaxial surface of the needles (Figure 2I). There is no difference at nuclear number between the isolate $\mathrm{Ts}_{06}$ and $\Delta \mathrm{Ts}_{06}$ except the uredial stage and its infection structures (Supplementary Figure 1).

\section{Pathogenicity and Biomass of $\Delta \mathrm{Ts}_{06}$}

Except for the incompatible host $P$. deltoides, $\Delta \mathrm{Ts}_{06}$ showed more compatibility and shortened the latent period by approximately 1 day compared with $\mathrm{Ts}_{06}$ on the other four hosts (Table 1). No significant difference was noted between $\Delta \mathrm{Ts}_{06}$ and $\mathrm{Ts}_{06}$ regarding uredinium diameter and height, but the density of $\Delta \mathrm{Ts}_{06}$ was significantly higher than that of $\mathrm{Ts}_{06}$ on the four hosts ( $p$ value $<0.05$ ) (Supplementary Figure 2), and the fungal colonies in $\Delta \mathrm{Ts}_{06}-P$. purdomii stained by trypan blue were much more in number than the colonies in $\mathrm{Ts}_{06}-P$. purdomii 
(Supplementary Figure 3). These results showed a bigger fungal biomass for $\Delta \mathrm{Ts}_{06}$ infection. The qRT-PCR of ITS also displayed fungal biomass of $\Delta \mathrm{Ts}_{06}$ and yielded higher than did $\mathrm{Ts}_{06}$, and both strains increased their biomass since $2 \mathrm{dpi}$ and reached a maximum at $7 \mathrm{dpi}$ (Figure 3). During $0 \sim 24 \mathrm{~h}$ after both $\Delta \mathrm{Ts}_{06}$ and $\mathrm{Ts}_{06}$ were inoculated with $P$. purdomii, no significant change was noted in the expression of SSP (Figure 3). However, at the 48th $\mathrm{h}$, the expression level of protein 37347 was significantly higher in $\Delta \mathrm{Ts}_{06}$ than in $\mathrm{Ts}_{06}$, and $\Delta \mathrm{Ts}_{06}$ produced more haustoria than $\mathrm{Ts}_{06}$. At the 96th hour, the expression levels of four proteins $(37347,124530,123932$, and 124272) were significantly higher in $\Delta \mathrm{Ts}_{06}$ than in $\mathrm{Ts}_{06}$, and $\Delta \mathrm{Ts}_{06}$ produced more intercellular hyphae than $\mathrm{Ts}_{06}$. At the 168th $\mathrm{h}$, the expression levels of three proteins $(123932,124272$, and 124256) were significantly higher in $\Delta \mathrm{Ts}_{06}$ than in $\mathrm{Ts}_{06}$, and $\Delta \mathrm{Ts}_{06}$ produced more urediniospores than $\mathrm{Ts}_{06}$.

\section{Differentially Expressed Genes Associated With Temperature and Time}

An average of $42.5 \mathrm{M}$ of clean reads per sample were collected (Supplementary Table 2). A total of 10,496 genes were detected, among which 9,869 genes were known and 627 new genes were predicted. Q30 (percentage of bases with quality $>30$ in clean reads) for each sample was approximately $91 \%$. The proportion of mapped reads ranged from $70.49 \%$ to $76.74 \%$, and manifested RNA-Seq results were up to standard. There were 3,224 DEGs in the union of CK20 vs. One20, CK20 vs. Two20, CK80 vs. One80, and CK80 vs. Two80; and a total of 55 genes intersected (Figure 4A). Of these 55 genes, 30 were upregulated and 25 were downregulated (Figure 4B). The top five upregulated genes were related to "nucleic acid binding" (MELLADRAFT_61177 and MELLADRAFT_73151), "fatty acid elongation" (MELLADRAFT_27551), "transmembrane transporter activity" (MELLADRAFT_37062), and "reactive oxygen species metabolic process" (MELLADRAFT_90189). The top five downregulated genes were related to "catalytic activity" (MELLADRAFT_69806), the "intrinsic component of membrane" (MELLADRAFT_72555, MELLADRAFT_124068, and MELLADRAFT_90128), and the "oxidoreductase activity" (MELLADRAFT_93496).

The GO analysis of these 55 genes revealed that the enriched items primarily included "drug metabolism" (GO: 0017144), "reactive oxygen species metabolism" (GO: 0072593), "antibiotic metabolism" (GO: 0016999), and "response to oxidative stress" (GO: 0006979) (Figure 5A). According to the KEGG analysis of the 55 genes, the primary enrichment pathways were the "MAPK signaling pathway" (ko04011), the "meiosis" (ko04013), the "longevity regulating pathway" (ko04213), the "cell cycle" (ko04111), and the "linoleic acid metabolism" (ko01212) (Figure 5B). Compared with the STRING database, the 55 genes formed a protein network diagram of 10 core genes (Figure 6A), which were annotated as "regulation of cellular metabolic process" (MELLADRAFT_84720), "trehalose biosynthetic process" (MELLADRAFT_60322), "response to oxidative stress" (MELLADRAFT_87433), "superoxide dismutase activity" (MELLADRAFT_43851), "DNA replication initiation" (MELLADRAFT_115157), "nucleic acid metabolic process” (MELLADRAFT_104525, BGI_novel_104525), "nuclear division" (MELLADRAFT_36075), "protein kinase activity" (MELLADRAFT_102486), and "nucleic acid binding" (MELLADRAFT_61177). Six of these 10 core genes are believed to be key genes in the mitotic and meiosis pathways (Figure 6B).

\section{Verification of Differentially Expressed Genes Using qRT-PCR}

Ten genes in the mitotic and meiosis pathways and two genes of "responses to DNA damage stimulus" were selected for qRTPCR verification (Figure 6C). The expression of qRT-PCR was consistent with FPKM (fragments per kilobase of transcript per million fragments mapped) analysis of the transcriptome. All three genes (MELLADRAFT_47540, MELLADRAFT_33683, and MELLADRAFT_73904) at the beginning of the nuclear division pathway were upregulated, which suggested that these genes responded to cryopreservation stimuli. The expressions of MELLADRAFT_102486 (PKA) in One20 and Two20 were significantly higher than those in CK20, and the expression in Two80 was significantly higher than that in One 80 and CK80, indicating that the protein kinase was more active in 2-year preservation than in both the 1-year and the contrast. The expression level of MELLADRAFT_61177 (Msn2,4) in Two20 was significantly higher than the levels in CK20 and One20, and the expression in Two 80 was also significantly higher than the levels in One80 and CK80, showing that as the temperature lowered and time increased, the expression became higher. The expression levels of MELLADRAFT_110829 (Sak2) in both Two20 and One20 were significantly higher than those in CK20, and the expressions in Two80 and One80 were also significantly higher than that in CK80, indicating that both Msn2,4 and Sak2 were regulated by the upstream gene PKA. The expression of BGI-novel_G000167 (ORC) related to nucleic acid metabolism in CK20 was significantly higher than the levels in One20 and Two20, but the expression in Two 80 was significantly higher than the levels in One80 and CK80. The expression of MELLADRAFT_115157 (MCM) in CK20 was significantly higher than the levels in One20 and Two20, which was consistent with its upstream gene (ORC) expression, but its expression in Two80 was significantly higher than the levels in CK80 and One80. Since the ORC and MCM genes are both upstream meiotic genes, cryopreservation at $-80^{\circ} \mathrm{C}$ for 2 years (as in CK20) was determined to accelerate meiotic progression. The expression level of MELLADRAFT_104525 (Spo11) in Two20 was significantly higher than the levels in CK20 and One20, and its expression in Two80 was significantly higher than the levels in CK80 and One80, suggesting an upward trend in DNA replication as cryopreservation time increased. The expression levels of MELLADRAFT_36075 (DMC1) in Two20 and One20 were significantly higher than those in CK20, and the expression in Two 80 was significantly higher than the levels in One80 and CK80, exhibiting an upward trend of nuclear division similar to its upstream gene Spo11. The expression levels of DMC1 and Spo11 accelerated mitosis progression, and a longer cryopreservation time enabled higher 

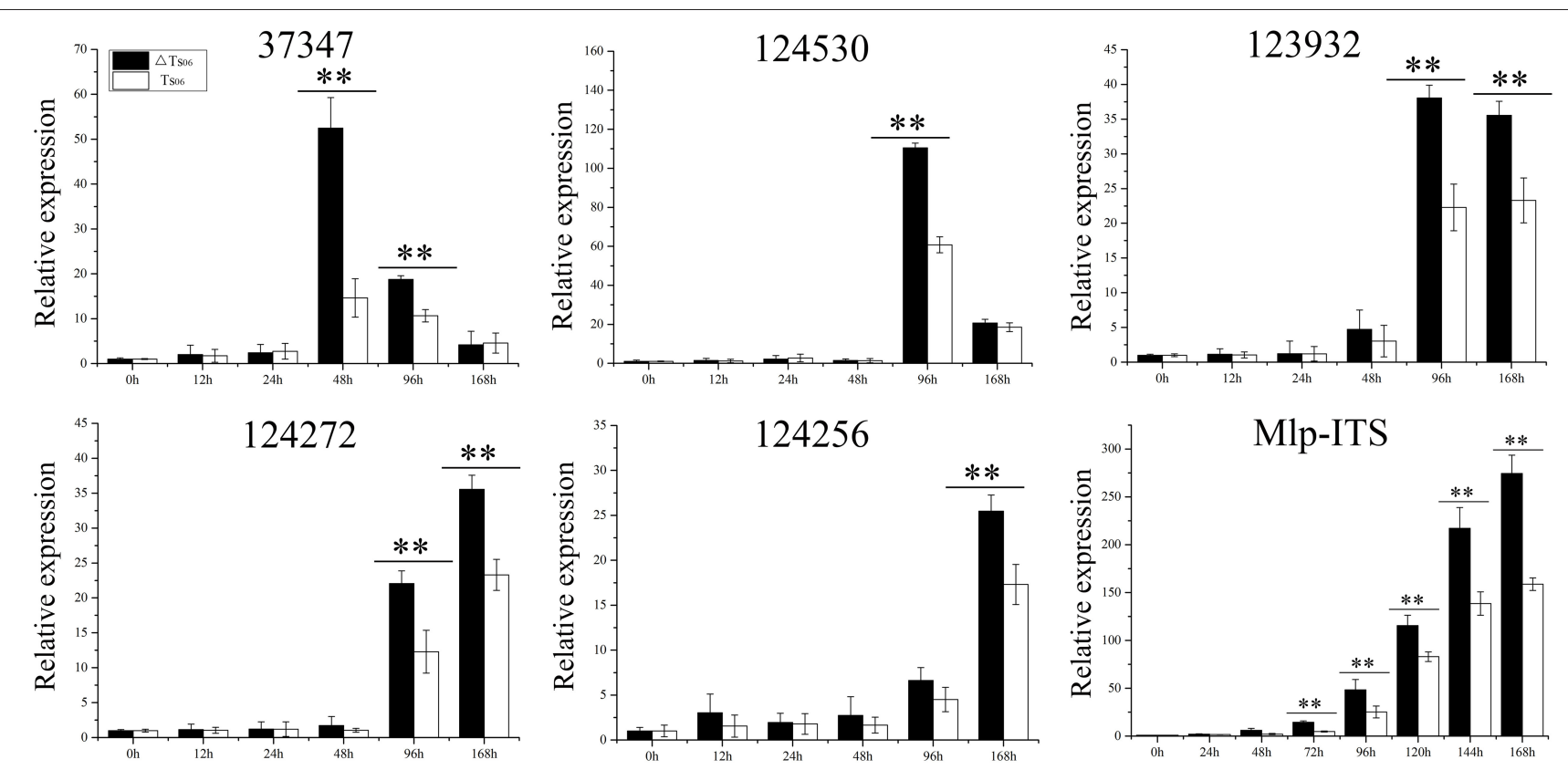

FIGURE 3 | qRT-PCR of small secreted proteins (SSP) in $\Delta \mathrm{Ts}_{06}$ and Ts 06 during Populus purdomii infection. Labeling error lines were obtained from three biological repetitions. Significant differences are indicated by ** $(p$ value $<0.01)$.

activity in nuclear mitosis. Two80 displayed strong dynamics in both mitosis and meiotic progression. Another two genes of "responses to DNA damage stimulus" (BGI-novel_G000377 and MELLADRAFT_112356) were upregulated, which hinted that the DNA damage of urediniospores became more severe as cryopreservation time increased (Figure 6C).

\section{$\mathrm{H}_{2} \mathrm{O}_{2}$ Concentration and Fatty Acid Content in Urediniospores}

The concentrations of $\mathrm{H}_{2} \mathrm{O}_{2}$ in Two20 and Two80 were significantly higher than those in One20 and One80, while the concentrations of $\mathrm{H}_{2} \mathrm{O}_{2}$ in One 20 and One 80 were significantly higher than those in CK20 and CK80 (Figure 7A). This result indicated that "reactive oxygen species" (ROS) increased as cryopreservation time increased, and the result agreed with the transcriptome results (Figure 7B) that longer preservation time increased the superoxide content. Seven fatty acid components were massive in the urediniospores of both $\Delta \mathrm{Ts}_{06}$ and $\mathrm{Ts}_{06}$, six of which (hexadecanoic acid, 9,12-octadecadienoic acid, and 9,12,15-octadecatrienoic acid, etc.) were found in greater quantities in $\Delta \mathrm{Ts}_{06}$ than in $\mathrm{Ts}_{06}$ (Supplementary Table 3).

\section{Comparison of Genotypes of $\Delta \mathrm{Ts}_{06}$ and $\mathrm{Ts}_{06}$}

The DNA profile from RAM amplification showed that the two strains had different fragments, although only four primers were employed in this study. However, a difference in genomic DNA was detected. This result indicated that genotype variation occurred between the two strains during cryopreservation (Supplementary Figure 4).

\section{DISCUSSION}

Nuclear mutation is a main way to form multinucleation phenomena (Roper et al., 2011). The leading cause of nuclear mutation is abnormal mitosis (Yoshida et al., 2007; Wang et al., 2013). Apopa et al. (2009) reported that the presence of excessive ROS in cells resulted in abnormal mitosis and multinuclear cells. This study identified 55 DEGs at the intersection of CK20 vs. One20, CK20 vs. Two20, CK80 vs. One80, and CK80 vs. Two80. According to the GO enrichment analysis of these 55 genes, "reactive oxygen species metabolism" and "response to oxidative stress" are two items that possess many enriched genes, and each of them is enriched with seven genes (Figure 5A). The functional annotation "reactive oxygen species” (MELLADRAFT_90189, MELLADRAFT_124101, MELLADRAFT_73483, and MELLADRAFT_87433) was significantly upregulated in One20, Two20, One80, and Two80 (Figure 7B). Correspondingly, the concentrations of $\mathrm{H}_{2} \mathrm{O}_{2}$ in urediniospores of both Two20 and Two80 were significantly higher than those in CK20 and CK80 (Figure 7A). The expression levels of the two genes of "responses to DNA damage stimulus” (BGI-novel_G000377 and MELLADRAFT_112356) were significantly higher in One20, Two20, One80, and Two80 than those in CK20 and CK80 (Figure 6C). These results indicated that $\mathrm{Ts}_{06}$ stored at $-80^{\circ} \mathrm{C}$ increased the expression of ROS in urediniospores, which resulted in damage to nuclear DNA and eventually led to abnormal nuclear mitosis and the formation of polynuclear spores. Meiosis is believed not to occur during the uredinia stage in the life cycle, but synapses can be found before haploid karyon fusion in M. larici-populina. In this study, the S-phase progression genes, ORC and MCM, 
A

B

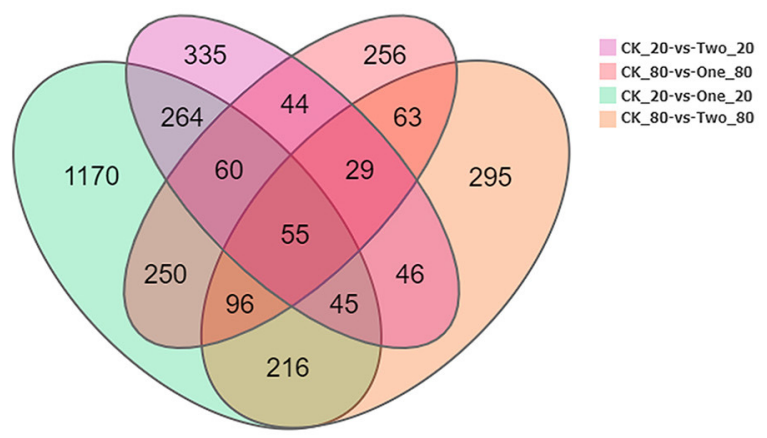

ำ

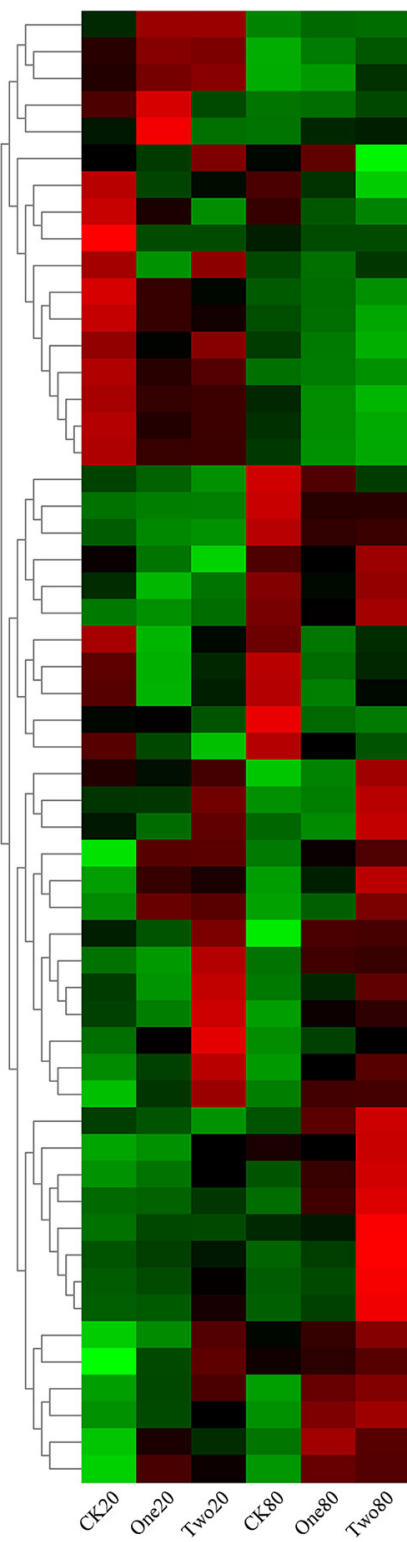

MELLADRAFT 91461 KEGG: uncharacterized protein

MELLADRAFT_36075 GO: nuclear division; catalytic activity

MELLADRAFT_95481 GO: peroxiredoxin activity; response to oxidative stress

MELLADRAFT_114138 GO: autophagy; catabolic process

MELLADRAFT 74892 GO: cellular response to oxygen-containing compound

MELLADRAFT_79538 GO: intrinsic component of membrane

MELLADRAFT_93496 GO: oxidoreductase activity

MELLADRAFT_51995 GO: carbohydrate metabolic process

MELLADRAFT 78470 GO: catalytic activity

MELLADRAFT_31636 GO: transcription regulator activity; nucleus

MELLADRAFT_117051 GO: hydrolase activity; extracellular region part

MELLADRAFT $33800 \quad$ GO: sulfate assimilation; kinase activity

MELLADRAFT_105917 GO: cytoplasm; catalytic activity

BGI_novel_G000571 GO: transport; cytoplasm

MELLADRAFT_124068 GO: integral component of membrane

MELLADRAFT 72555 GO: intrinsic component of membrane

MELLADRAFT 90128 GO: intrinsic component of membrane

MELLADRAFT_88487 GO: intrinsic component of membrane

BGI_novel_G000594 GO: nucleic acid binding

MELLADRAFT 94008 GO: metal ion binding

MELLADRAFT 115157 GO: DNA replication initiation; nucleus

BGI_novel_G000167 GO: nucleic acid metabolic process; chromosome

MELLADRAFT_91915 KEGG: serine/threonine-protein phosphatase 2A regulatory subunit A

MELLADRAFT_ 89096 GO: intrinsic component of membrane

MELLADRAFT_61460 GO: intrinsic component of membrane

MELLADRAFT_75188 GO: hydrolase activity; carbohydrate metabolic process

MELLADRAFT 69806 GO: catalytic activity

MELLADRAFT 85678 GO: cytoplasmic part; exocytic process

MELLADRAFT_87433 GO: response to oxidative stress; peroxisome

MELLADRAFT_102041 GO: metal ion binding

MELLADRAFT 104525 GO: DNA binding; chromosome; nucleic acid metabolic process

MELLADRAFT 85533 GO: nucleic acid binding; nucleus; cellular response to oxidative stress

MELLADRAFT_124101 GO: reactive oxygen species metabolic process

MELLADRAFT_73483 GO: cellular response to reactive oxygen species

MELLADRAFT_38712 GO: catalase activity; response to oxidative stress

MELLADRAFT_43851 GO: superoxide dismutase activity

MELLADRAFT_33674 GO: cellular response to stimulus; GTPase activity

MELLADRAFT_49384 GO: membrane part; ATPase activity, coupled

MELLADRAFT 90189 GO: reactive oxygen species metabolic process

MELLADRAFT_61177 GO: nucleic acid binding

MELLADRAFT_93407

MELLADRAFT 40847

MELLADRAFT 73507

MELLADRAFT 60322

MELLADRAFT_84720

MELLADRAFT_10248

MELLADRAFT 76882

MELLADRAFT_27551

MELLADRAFT_37062

BGI novel G000377

MELLADRAFT 86876

MELLADRAFT_112356

MELLADRAFT_73151

BGI novel G000381

MELLADRAFT_73586

GO: oxidoreductase activity; carbohydrate metabolic process

GO: reactive oxygen species metabolic process; response to stimulus

GO: integral component of membrane

GO: cytoplasm; trehalose biosynthetic process

GO: regulation of cellular metabolic process

GO: protein kinase activity

GO: peroxidase activity; response to oxidative stress

GO: fatty acid elongation, unsaturated fatty acid

GO: transmembrane transporter activity

GO: organelle; regulation of response to DNA damage stimulus

KEGG: serine/threonine-protein kinase BUR1

GO: response to stimulus; cellular response to DNA damage stimulus

GO: nucleic acid binding

GO: ATPase activity; intracellular organelle part; response to stress

GO: galactosyltransferase activity; membrane part

FIGURE 4 | Differentially expressed genes (DEGs) at different cryopreservation temperatures. (A) Venn diagram showing the number of differentially expressed genes. (B) Cluster heat map of intersectional gene expressions. 
A

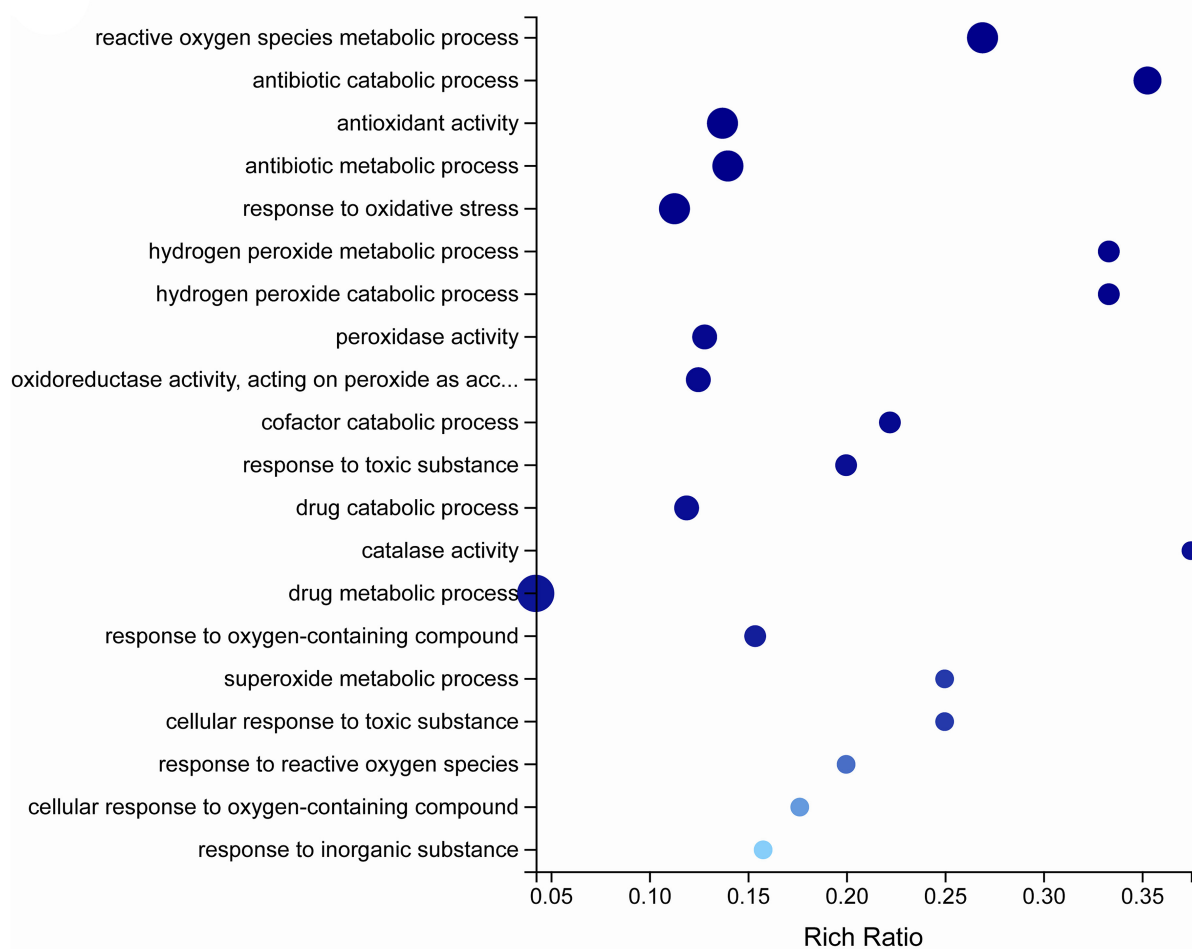

\section{KEGG Pathway}

B

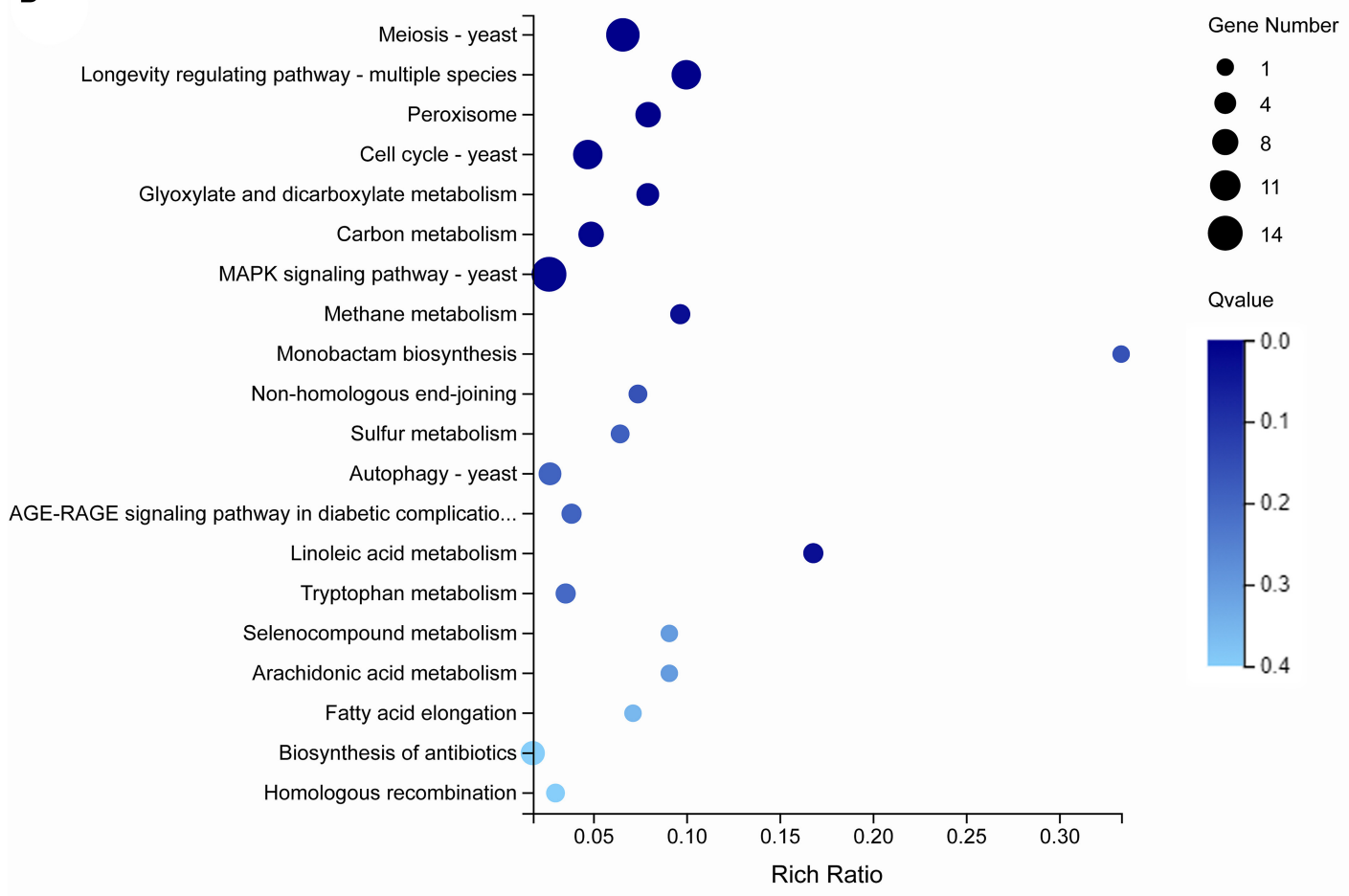

FIGURE 5 | Gene Ontology (GO) and Kyoto Encyclopedia of Genes and Genomes (KEGG) analysis of differentially expressed genes (DEGs). (A) GO enrichment bubble diagram. (B) KEGG enrichment pathway diagram. 
A

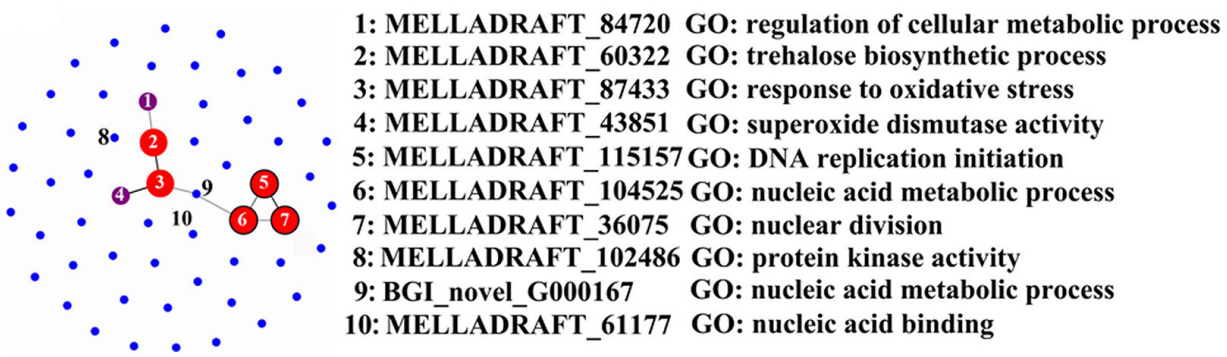

B

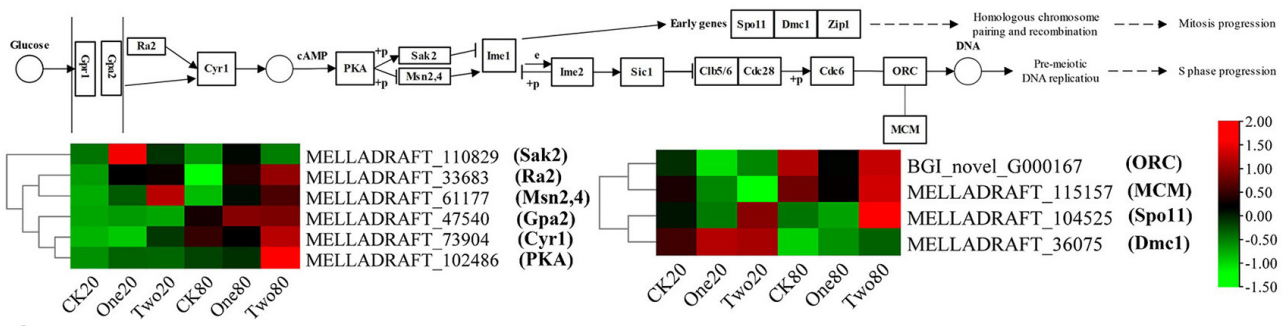

C
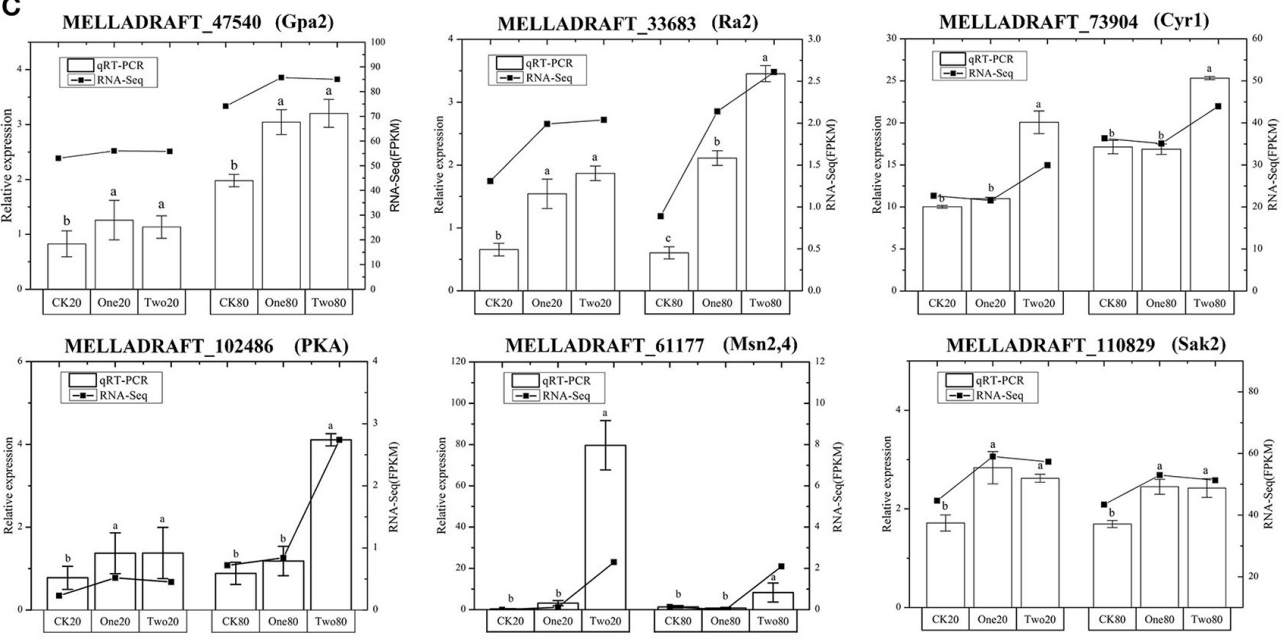

MELLADRAFT_104525 (Spo11)
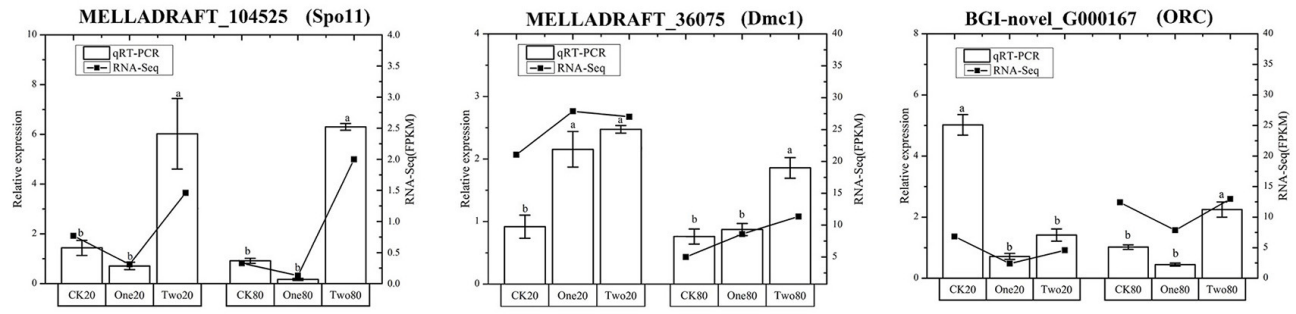

MELLADRAFT 115157 (MCM)
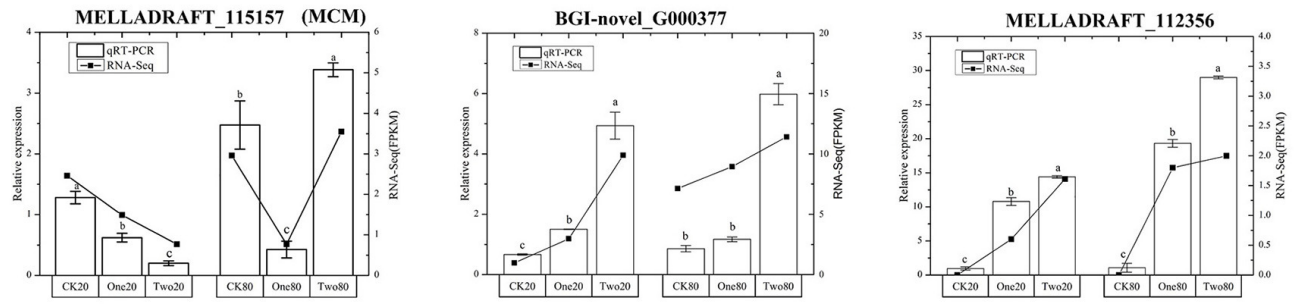

FIGURE 6 | qRT-PCR verification of differentially expressed genes (DEGs). (A) Protein network diagram of DEGs. (B) Gene regulation pathway map of the G2 stage of mitosis and the S stage of meiosis. (C) qRT-PCR of DEGs. Note: Each point in the graph represents one gene, and the connecting lines between the two genes indicate that two genes interact. The size and color of the dots indicate the number of interactive connections, larger dots indicate that there are more connections, the color gradually changes from blue to red, and red indicates more connections. The range from green to red in (B) indicates the gene FPKM (fragments per kilobase of transcript per million fragments mapped) value. The error lines marked in (C) are obtained from three biological repetitions, and the significant differences are indicated by $\mathrm{a}, \mathrm{b}$, and $\mathrm{c}$. 


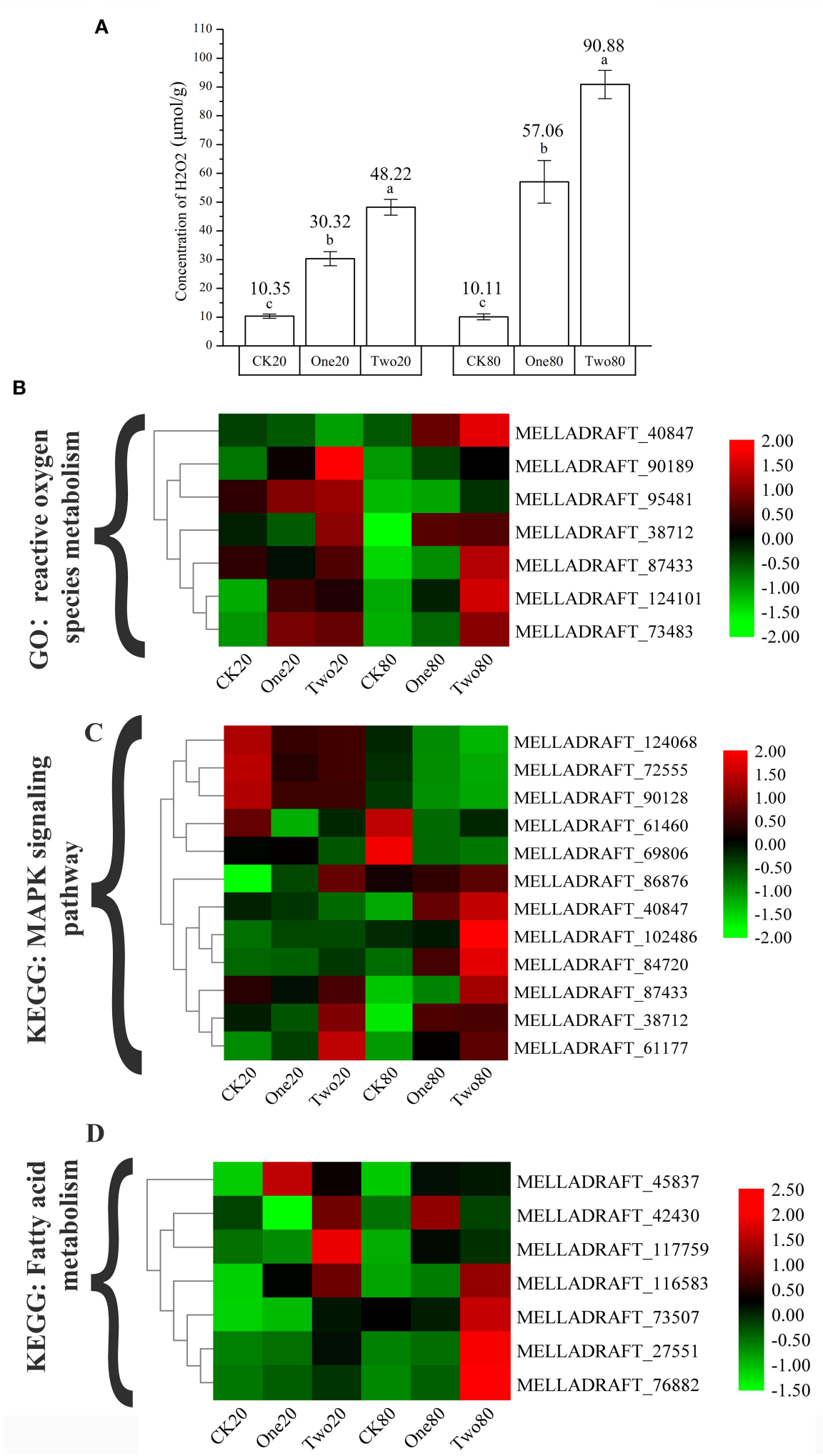

FIGURE 7 | Determination of the concentrations of $\mathrm{H}_{2} \mathrm{O}_{2}$ in different samples and the cluster heat map of different gene expressions. (A) Determination of the concentrations of $\mathrm{H}_{2} \mathrm{O}_{2}$. (B) The genes of "reactive oxygen species metabolic process." (C) The genes of "MAPK signaling pathway." (D) The genes of "fatty acid metabolism." Different letters mean significant differences at the 0.05 level. 
which may also be involved in the formation of polykaryon, were upregulated at $-80^{\circ} \mathrm{C}$. The qRT-PCR analysis of 10 genes in the mitotic and meiotic pathways showed that the expression levels of three genes (MELLADRAFT_47540, MELLADRAFT_33683, and MELLADRAFT_73904) were upregulated, suggesting that these genes responded to environmental stimuli. Except for these genes, expressions of the protein kinase activity gene MELLADRAFT_102486 (PKA) and the nucleic acid metabolism gene MELLADRAFT_61177 $(M s n 2,4)$ also increased, and the downstream genes related to mitosis and S-phase meiotic division were both activated. For example, MELLADRAFT_36075 (Dmc1), MELLADRAFT_104525 (Spo11), BGI-novel_G000167 (ORC), and MELLADRAFT_115157 (MCM) exhibited upward trends of expression at $-80^{\circ} \mathrm{C}$ as cryopreservation time increased. Abnormal mitosis and abnormal S-phase progression of urediniospore nuclei in $\Delta \mathrm{Ts}_{06}$ were believed to cause polynuclear phenomena in this study.

Mitogen-activated protein kinases (MAPKs) are important factors in eukaryotic signaling networks (Bögre et al., 1999). The MAPK signal cascade is crucial for sensing environmental stimuli on the cell surface and transmitting these signals to the nucleus to regulate gene expression (Qi and Elion, 2005). Most of the 55 KEGG-annotated DEGs were in the MAPK signaling pathway. Of these 55 genes, MELLADRAFT_84720, MELLADRAFT_87433, MELLADRAFT_102486, and MELLADRAFT_61177 were also found in the networks of interactive proteins (Figures 6A, 7C). Furthermore, MELLADRAFT_102486 and MELLADRAFT_61177 are upstream genes in mitosis and meiosis, and they both showed an upward expression trend during cryopreservation, which suggested that the MAPK signaling pathway played an important regulatory role in abnormal nuclear division.

Transcriptome sequencing revealed that genes associated with "fatty acid metabolism" (MELLADRAFT_117759, MELLADRAFT_73507, MELLADRAFT_45837, and MELLADRAFT_27551) and "trehalose biosynthesis process" (MELLADRAFT_60322) were significantly upregulated (Figure 7D). Trehalose is widely noted in bacteria, fungi, and plants (Avonce et al., 2006). In fungi, trehalose is often used as a carbon storage source and responds adaptively to various pressure conditions (Thevelein, 1984; Gancedo and Flores, 2004), including dehydration, oxidative stress, heat treatment, cold treatment, and freezing stress (Sasano et al., 2012; Zakharova et al., 2012). Notably, fatty acids affect the biochemical activity, transfer process and stimulation of cells, and participate in several physiological processes, including lipid metabolism, cell recognition, immune response, and cold adaptation (Grammatikos et al., 1994; Jump et al., 1996). The metabolism of fatty acids and trehalose in urediniospores increased during the cryopreservation (Supplementary Table 3); this increase in metabolism hinted an improvement of urediniospores to resist damage due to low temperatures.

Many studies have shown that avirulence genes or effectors encoded by pathogenicity-related genes are secreted proteins (Zhang et al., 2020), and secreted proteins are assumed to be key molecules for pathogenicity (Petre et al., 2014). For example, AvrL567 and AvrP4 are secreted proteins in M. lini (Petre et al.,
2014). Avirulence gene is one of the important SSP genes, which often appears in the form of a gene family and plays a role during the infection (Dodds et al., 2004). In this study, the expressions levels of five SSPs homologous with avirulence genes of M. lini were used to compare the pathogenicity of $\Delta \mathrm{Ts}_{06}$ and $\mathrm{Ts}_{06}$ during the infection. The levels were significantly higher in $\Delta \mathrm{Ts}_{06}$ than in $\mathrm{Ts}_{06}$ at 48,96 , and $168 \mathrm{~h}$ probably because $\Delta \mathrm{Ts}_{06}$ produced much more haustoria, intercellular hyphae, and urediniospores than $\mathrm{Ts}_{06}$ did. In addition, the higher urediniospore density and shorter latent period of $\Delta \mathrm{Ts}_{06}$ on the compatible host P. purdomii also validated these SSP expressions, and $\Delta \mathrm{Ts}_{06}$ displayed more compatibility and more pathogeneticity with $P$. purdomii. Furthermore, the RAM screen based on genomic DNA determined that the genotype of $\Delta \mathrm{Ts}_{06}$ was different from that of the isolate $\mathrm{Ts}_{06}$. Cryopreservation changed both the phenotype and genotype of isolate $\mathrm{Ts}_{06}$.

The nuclear behavior in the life cycle of rust fungi is of great significance for understanding individual inheritance, interspecific evolutionary, and intraspecific pathogenicity variation of rust fungi. Except for Uredinales imperfecti, all rust fungi have telial stages in their life cycle. Teliospores are diploid cells that need two haploid nuclei to fuse before they can germinate and start the life cycle. Germination of teliospores is the most important event in the life cycle of rust fungi because both karyogamy and meiosis occur at this stage. In fact, meiosis occurs before the germination of teliospores. After karyogamy, diploid cells quickly complete homologous chromosome pairing, and the synaptonemal complex is produced in the dormant period (Mims and Richardson, 2005). The genes related to prophase I, such as the Spo11 protein gene in the leptotene stage, the tetrad-forming kinase Hop1 gene in the zygotene stage, Rad51 and Mnd1 in the pachytene stage, and karyokinesis genes were significantly upregulated (Hacquard et al., 2013). However, due to the differences in the time and position of karyogamy among different rusts, the shape of basidium (promycelium) produced by teliospores, the cell position during meiosis, the number of basidiospores, the times of re-germination of basidiospores, and the nuclear status are all obviously different (Shimomura et al., 2012), which indicate a diversity of life cycles. Furthermore, Jackson (1935) described seven types of nuclear behaviors of microcyclic rust, Petersen (1974) described six types, Hiratsuka and Sato (1982) described eight types, and Ono (2002) described 10 types and 21 subtypes of microcyclic rust. In this study, the telial and basidial stages of polykaryon $\Delta \mathrm{Ts}_{06}$ were not different than those in a typical macrocyclic M. larici-populina; how polykaryotic somatic hyphae develop into karyogamy and how meiosis ultimately occurs are still not well understood.

Cummins and Hiratsuka (1983) thought that heteroecious macrocyclic rust often shortened the life cycle and formed the corresponding species. In a disturbed ecosystem, macrocyclic rust may lose the opportunity and the ability to complete heterosexual mating and evolve from the unstable parent population. This repeated evolution makes up for the danger of macrocyclic rust dying out in harsh evolutionary environments, and thus, many branches of microcyclic rust are produced and distributed in different niches (Hennen and Buritica, 1980). For example, Peridermium yamabense is a synonym for Endocronartium yamabense because it cannot form real 
teliospores and is the asexual type of Cronartium ribicola (Imazu et al., 1991). Zemodeme I of E. harknessii ( $\equiv$ P. harknessii) and C. quercuum are highly similar. Zemodeme II originates from zemodeme I after karyogamy, or the latter is a haploid from the former (Vogler et al., 1997). Another example is the leaf rust Rubus sp., which has three species. One is the demicyclic rust Gymnoconia peckiana, which forms vegetative aeciospores on the leaves and germinates to produce binuclear germ tubes and an appressorium. The other two species are endocyclic rust G. nitens, which can produce aeciospore-type teliospores on leaves. One of the $G$. nitens species germinates to form a two-cell basidium and produces two haploid basidiospores, whereas the other one forms four-cell basidiospores and grows four basidiospores. In four-cell basidiospores, two nuclei in aeciospore-type teliospores do not undergo karyogamy and meiosis but rather is formed by direct division of the binucleate form (Mims et al., 2007). The multinucleation phenomenon produced by urediniospores stored during cryopreservation is an important basis for the diverse evolution of the life cycle of M. larici-populina, which is of great significance for improving the adaptability of rust fungi to low-temperature environments, genetic variation, and host selection.

\section{CONCLUSION}

Cryopreservation can change both the phenotype and genotype of isolate $\mathrm{Ts}_{06}$. The multinuclear isolate $\Delta \mathrm{Ts}_{06}$ has stronger host compatibility, pathogenicity, and environmental adaptability than $\mathrm{Ts}_{06}$ has. Transcriptomics suggested that the fatty acids metabolism in cryopreserved urediniospores increased, which improved the ability of urediniospores to resist damage caused by ultralow temperatures. Cryopreservation triggered the MAPK signaling pathway and led to an increase in reactive oxygen metabolism in urediniospores; then, nuclear DNA damage and abnormal mitosis and meiosis processes facilitated the formation of polykaryotic urediniospores. In the continuous subculture, the proportion of polykaryotic urediniospores of $\Delta \mathrm{Ts}_{06}$ exhibited no significant change. At the 0 , I, III, and IV stages in the life cycle, the number of nuclei is not different between $\Delta \mathrm{Ts}_{06}$ and $\mathrm{Ts}_{06}$. The

\section{REFERENCES}

Allen, R. F. (1935). A cytoiogical study of Puccinia malvacearum from the sporidium to the tetiospore. J. Agric. Res. 51, 801-818.

Anderson, C. A., Roberts, S., Zhang, H., Kelly, C. M., Kendall, A., Lee, C., et al. (2015). Ploidy variation in multinucleate cells changes under stress. Mol. Biol. Cell. 26, 1129-1140. doi: 10.1091/mbc.E14-09-1375

Apopa, P. L., Qian, Y., Shao, R., Guo, N. L., Schwegler-Berry, D., Pacurari, M., et al. (2009). Iron oxide nanoparticles induce human microvascular endothelial cell permeability through reactive oxygen species production and microtubule remodeling. Part. Fibre Toxicol. 6, 1-14. doi: 10.1186/1743-8 977-6-1

Avonce, N., Mendoza-Vargas, A., Morett, E., and Iturriaga, G. (2006). Insights on the evolution of trehalose biosynthesis. BMC Evol. Biol. 6, 1-15. doi: 10.1186/1471-2148-6-109

Bögre, L., Calderini, O., Binarova, P., Mattauch, M., Till, S., Kiegerl, S., et al. (1999). A MAP kinase is activated late in plant mitosis and becomes localized results indicated that this mutant strain had a certain stability and environmental adaptability. However, how the polykaryon strain completes binucleation and undergoes meiosis remains unclear.

\section{DATA AVAILABILITY STATEMENT}

The datasets generated for this study can be found in the NCBI Sequence Read Archive (PRJNA673784, https://www.ncbi.nlm. nih.gov/sra).

\section{AUTHOR CONTRIBUTIONS}

$\mathrm{ZY}$ and ZC conceived and planned the study. WZ performed the field investigation and characterization experiments and analyzed the data. ZY and WZ contributed key ideas, analyzed the data, and wrote the manuscript. ZP and SP assisted in the data analysis. All authors contributed to the article and approved the submitted version.

\section{FUNDING}

This research was funded by the National Natural Science Committee, grant number 31670650, and National Key Research Projects, grant number 2017YFD0600103-4-2.

\section{ACKNOWLEDGMENTS}

The author would like to thank Miss Ren $\mathrm{Na}$ at Northwest A\&F University for her help with English writing and Dr. Liu Xiaoyong at the Institute of Microbiology, Chinese Academy of Sciences, for his help in determining fatty acid compositions in urediniospores.

\section{SUPPLEMENTARY MATERIAL}

The Supplementary Material for this article can be found online at: https://www.frontiersin.org/articles/10.3389/fmicb. 2021.650902/full\#supplementary-material to the plane of cell division. Plant Cell 11, 101-113. doi: 10.1105/tpc. 11.1.101

Boyle, B., Hamelin, R. C., and Seguin, A. (2005). In vivo monitoring of obligate biotrophic pathogen growth by kinetic PCR. Appl. Environ. Microbiol. 71, 1546-1552. doi: 10.1128/AEM.71.3.1546-1552.2005

Chandrasbekar, M., and Heather, W. A. (1980). Reactions of poplar clones to physiologic races of Melampsora larici-populina Kleb. Euphytica 29, 401-407. doi: 10.1007/BF00025139

Chen, C., Chen, H., Zhang, Y., Thomas, H. R., Frank, M. H., and He, Y. (2020). TBtools: an integrative toolkit developed for interactive analyses of big biological data. Mol. Plant. 13, 1194-1202. doi: 10.1016/j.molp.2020.06.009

Cummins, G. B., and Hiratsuka, Y. (1983). Illustrated Genera of Rust Fungi, 3rd edn. Vol. 53. St Paul, Minn. The American Phytopathological Society, 9-29.

Dang, F. F., Wang, Y. N., Eulgem, T., Lai, Y., Liu, Z. Q., and Wang, X. (2013). CaWRKY40, a WRKY protein of pepper, plays an important role in the regulation of tolerance to heat stress and resistance to Ralstonia solanacearum infection. Plant Cell Environ. 36, 757-774. doi: 10.1111/pce.12011 
Dodds, P. N., Lawrence, G. J., Catanzariti, A. M., Ayliffe, M. A., and Ellis, J. G. (2004). The Melampsora lini AvrL567 avirulence genes are expressed in haustoria and their products are recognized inside plant cells. Plant Cell. 16, 755-768. doi: $10.1105 /$ tpc. 020040

Gancedo, C., and Flores, C. L. (2004). The importance of a functional trehalose biosynthetic pathway for the life of yeasts and fungi. FEMS Yeast Res. 4, 351-359. doi: 10.1016/S1567-1356(03)00222-8

Grammatikos, S. I., Subbaiah, P. V., Victor, T. A., and Miller, W. M. (1994). Diverse effects of essential (n-6 and n-3) fatty acids on cultured cells. Cytotechnology 15, 31-50. doi: 10.1007/BF00762377

Hacquard, S., Delaruelle, C., Frey, P., Tisserant, E., Kohler, A., and Duplessis, S. (2013). Transcriptome analysis of poplar rust telia reveals overwintering adaptation and tightly coordinated karyogamy and meiosis processes. Front. Plant Sci. 4, 1-14. doi: 10.3389/fpls.2013. 00456

Hacquard, S., Joly, D. L., Lin, Y. C., Tisserant, E., Feau, N., and Delaruelle, C. (2012). A comprehensive analysis of genes encoding small secreted proteins identifies candidate effectors in Melampsora larici-populina (poplar leaf rust). Mol. Plant Microbe Interact. 25, 279-293. doi: 10.1094/MPMI-09$11-0238$

Hacquard, S., Petre, B., Frey, P., Hecker, A., Rouhier, N., and Duplessis, S. (2011). The poplar-poplar rust interaction: insights from genomics and transcriptomics. J. Pathog. 2011, 1-12. doi: 10.4061/2011/716041

Hantula, J., Dusabenyagasani, M., and Hamelin, R. C. (1996). Random amplified microsatellites (rams)-a novel method for characterizing genetic variations within fungi. Eur. J. For. Path. 26, 159-166. doi: 10.1111/j.1439-0329.1996.tb00720.x

Heath, M. C., Xu, H. X., and Eilam, T. (1996). Nuclear behavior of the cowpea rust fungus during the early stages of basidiospore or urediospore-derived growth in resistant of susceptible cowpea cultivars. Phytopathology 86, 1057-1065. doi: 10.1094/Phyto-86-1057

Hennen, J. F., and Buritica, C. P. (1980). A brief summary of modern rust [Fungus] taxonomic and evolutionary theory. Rep. Totori Mycol. Inst. 18, 243-256.

Hiratsuka, Y., and Sato, S. (1982). "Morphology and taxonomy of rust fungi," in The Rust Fungi, Vol. 1, eds K., Scott, A. K., Chakravorty (New York, NY: Academic Press), 1-36.

Huang, S., Chueh, P. J., Lin, Y. W., Shih, T. S., and Chuang, S. M. (2009). Disturbed mitotic progression and genome segregation are involved in cell transformation mediated by nano-TiO2 long-term exposure. Toxicol. Appl. Pharmacol. 241, 182-194. doi: 10.1016/j.taap.2009.08.013

Imazu, M., Kakishima, M., and Kstuya, K. (1991). Morphology and nuclear cycle of Endocronartiurn yarmabense. Trans Mycol. Soc. Jpn. 32, 371-379.

Jackson, H. S. (1935). The nuclear cycle in Herpobasidium filicinum with a discussion of the significance of homothallism in Basidiomycetes. Mycologia. 27, 553-572. doi: 10.1080/00275514.1935.12017100

Jump, D. B., Clarke, S. D., Thelen, A., Liimatta, M., Ren, B., and Badin, M. (1996). Dietary polyunsaturated fatty acid regulation of gene transcription. Prog. Lipid Res. 35, 227-241. doi: 10.1016/S0163-7827(96)00007-0

Kang, Z. S., and Buchenauer, H. (2000). Ultrastructural and immunocytochemical investigation of pathogen development and host responses in resistant and susceptible wheat spikes infected by Fusarium culmorum. Physiol. Mol. Plant Pathol. 57, 255-268. doi: 10.1006/pmpp.2000.0305

Kang, Z. S., Wang,., X. J., Zhao, J., Tang, C. L., and Huang, L. L. (2015). Advances in research of pathogenicity and virulence variation of the wheat stripe rust fungus Puccinia striiformis f. sp. tritici. Scientia Agricultura Sinica. 48, 3439-3453. doi: 10.3864/j.issn.0578-1752.2015.17.011

Kim, D., Langmead, B., and Salzberg, S. L. (2015). HISAT: a fast spliced aligner with low memory requirements. Nat. Methods. 12, 357-360. doi: 10.1038/nmeth.3317

Lahaye, T., and Bonas, U. (2001). Molecular secrets of bacterial type III effector proteins. Trends Plant Sci. 6, 479-485. doi: 10.1016/S1360-1385(01)02083-0

Li, B., and Dewey, C. N. (2011). RSEM: accurate transcript quantification from RNA-Seq data with or without a reference genome. BMC Bioinformatics 12:323. doi: $10.1186 / 1471-2105-12-323$

Little, R., and Manners, J. G. (1969). Somatic recombination in yellow rust of wheat (Puccinia striiformis): I. the production and possible origin of two new physiologic races. Trans. Br. Mycol. Soc. 53, 251-258. doi: 10.1016/S0007-1536(69)80059-8
Livak, K. J., and Schmittgen, T. D. (2001). Analysis of relative gene expression data using real-time quantitative PCR and the $2^{-\Delta \Delta C T}$ method. Methods 25 , 402-408. doi: 10.1006/meth.2001.1262

Lorrain, C., Santos, K. C. G., Hugo, G., Hecker, A., and Duplessis, S. (2019). Advances in understanding obligate biotrophy in rust fungi. New. Phytol. 222, 1190-1206. doi: 10.1111/nph.15641

Maheshwari, R. (2005). Nuclear behavior in fungal hyphae. FEMS Microbiol. Lett. 249, 7-14. doi: 10.1016/j.femsle.2005.06.031

Mims, C. W., and Richardson, E. A. (2005). Light and electron microscopy of teliospores and teliospore germination in the rust fungus Coleosporium ipomoeae. Can. J. Bot. 83, 451-458. doi: 10.1139/b05-020

Mims, C. W., Richardson, E. A., and Taylor, J. (2007). Ultrastructure of teliospores and promycelium and basidiospore formation in the foure-spored form of Gymnoconia nitens, one of the causes of orange rust of Rubus. Can. J. Bot. 85, 926-934. doi: 10.1139/B07-097

Newcombe, G. (1998). A review of exapted resistance to diseases of Populus. Eur. J. For. Pathol. 28, 209-216. doi: 10.1111/j.1439-0329.1998.tb01175.x

Ono, Y. (2002). The diversity of nuclear cycles in microcyclic rust fungi (Uredinales) and its ecological and evolutionary implications. Mycoscience 43, 421-439. doi: $10.1007 /$ S102670200062

Orth, K., Xu, Z., Mudgett, M. B., Bao, Z. Q., Palmer, L. E., and Bliska, J. B. (2000). Disruption of signalling by Yersinia effector YopJ, a ubiquitin-like protein protease. Science 290, 1594-1597. doi: 10.1126/science.290.5496.1594

Park, R. F., and Wellings, C. R. (2012). Somatic hybridization in the Uredinales. Аnnu. Rev. Phytopathol. 50, 219-239. doi: 10.1146/annurev-phyto-072910-095405

Pernaci, M., De Mita, S., Andrieux, A., Petrowski, J., Halkett, F., and Duplessis, S. (2014). Genome-wide patterns of segregation and linkage disequilibrium: the construction of a linkage genetic map of the poplar rust fungus Melampsora larici-populina. Front. Plant Sci. 5:454. doi: 10.3389/fpls.2014.00454

Petersen, R. H. (1974). The rust fungus life cycle. Bot. Rev. 40, 453-513. doi: 10.1007/BF02860021

Petre, B., Joly, D. L., and Duplessis, S. (2014). Effector proteins of rust fungi. Front. Plant Sci. 5:416. doi: 10.3389/fpls.2014.00416

Petre, B., Saunders, D., Sklenar, J., Lorrain, C., Win, J., and Duplessis, S. (2015). Candidate effector proteins of the rust pathogen Melampsora larici-populina target diverse plant cell compartments. Mol. Plant Microbe Interact. 28, 689-700. doi: 10.1094/MPMI-01-15-0003-R

Pinon, J., Dam, B. C. V., Genetet, I., and Kam, M. D. (1987). Two pathogenic races of Melampsora larici-populina in north-western Europe. Forest Pathol. 17, 47-53. doi: 10.1111/j.1439-0329.1987.tb00726.x

Pinon, J., and Frey, P. (1997). Structure of Melampsora larici-populina populations on wild and cultivated poplar. Eur. J. Plant Pathol. 103, 159-173. doi: 10.1023/A:1008650128568

Qi, M., and Elion, E. A. (2005). MAP kinase pathways. J. Cell Sci. 118, 3569-3572. doi: $10.1242 /$ jcs. 02470

Roper, M., Ellison, C., Taylor, J. W., and Glass, N. L. (2011). Nuclear and genome dynamics in multinucleate ascomycete fungi. Curr. Biol. 21, 786-793. doi: 10.1016/j.cub.2011.06.042

Sasano, Y., Haitani, Y., Hashida, K., Ohtsu,. I., Shima, J., and Takagi, H. (2012). Simultaneous accumulation of proline and trehalose in industrial baker's yeast enhances fermentation ability in frozen dough. J. Biosci. Bioeng. 113, 592-595. doi: 10.1016/j.jbiosc.2011.12.018

Savile, D. B. O. (1939). Nuclear structure and behavior in species of the Uredinales. Am. J. Bot. 26, 585-609. doi: 10.1002/j.1537-2197.1939.tb09322.x

Shimomura, N., Sawada, K., Aimi, T., Maekawa, N., and Matsumoto, T. (2012). Karyological characterization of meiosis, post-meiotic mitosis and nuclear migration in the ectomycorrhizal fungus Rhizopogon roseolus ( $=$ R. rubescens). Mycologia 104, 981-987. doi: 10.3852/11-279

Stark, R., Grzelak, M., and Hadfield, J. (2019). RNA sequencing: the teenage years. Nat. Rev. Genet. 20, 631-656. doi: 10.1038/s41576-019-0150-2

Steenackers, J., Steenackers, M., Steenackers, V., and Stevens, M. (1996). Poplar disease, consequences on growth and wood quality. Biomass Bioenerg. 10, 267-274. doi: 10.1016/0961-9534(95)00121-2

Taylor, E. (1976). "The production and behaviour of somatic recombinants in Puccinia striiformis," in Proceedings of European and Mediterranean Cereal Rusts Conference (Interlaken: Swiss Federal Research Station for Agronomy), 36-38 
Thevelein, J. M. (1984). Regulation of trehalose mobilization in fungi. Microbiol. Rev. 48, 42-59. doi: 10.1128/mr.48.1.42-59.1984

Vieira, A., Talhinhas, P., Loureiro, A., Duplessis, D. F., Silva, M. C., and Paulo, O. S. (2011). Validation of RT-qPCR reference genes for in planta expression studies in Hemileia vastatrix, the causal agent of coffee leaf rust. Fungal Biol. 115, 891-901. doi: 10.1016/j.funbio.2011.07.002

Virtudazo, E. V., Nakamura, H., and Kakishima, M. (2001). Phylogenetic analysis of sugarcane rusts based on sequences of ITS, 5.8 S rDNA and D1/D2regions of LSU rDNA. J. Gen. Plant. Pathol. 67, 28-36. doi: 10.1007/PL00012983

Vogler, D., Epstein, L., and Cobb, F. W. (1997). Nuclear behaviour and evolution of two populations of the western gall rust fungus. Mycol. Res. 101, 791-797. doi: $10.1017 /$ S0953756296003346

Wang, W., Yang, L., Liu, X. M., Jin, M. H., Du, H. Y., Liu, Y., et al. (2013). Multinucleation and cell dysfunction induced by amorphous silica nanoparticles in an L-02 human hepatic cell line. Int. J. Nanomed. 8, 3533-3541. doi: $10.2147 / \mathrm{IJN}$.S46732

Wang, Z., Gerstein, M., and Snyder, M. (2009). RNA-Seq: a revolutionary tool for transcriptomics. Nat. Rev. Genet. 10, 57-63. doi: 10.1038/nrg2484

Wilcoxon, R. D., Tuite, J. F., and Tucker, S. (1958). Urediospore germtube fusions in Puccinia graminis. Phytopathology. 48, 358-361.

Ye, J., Jin, C. F., Li, N., Liu, M. H., Fei, Z. X., Dong, L. Z., et al. (2018). Selection of suitable reference genes for qRT-PCR normalisation under different experimental conditions in Eucommia ulmoides Oliv. Sci. Rep. 8, 1-11. doi: 10.1038/s41598-018-33342-w

Yoshida, K., Obata, S., Ono, M., Esakiet, M., Maejima, T., and Sawada, H. (2007). TPA-induced multinucleation of a mesenchymal stem cell- like clone is mediated primarily by karyokinesis without cytokinesis, although cell-cell fusion also occurs. Eur. J. Cell. Biol. 86, 461-471. doi: 10.1016/j.ejcb.2007.04.003

Yu, Z. D., Liang, J., Cao, Z. M., Guo, Z. Q., Dan, J. Y., and Zhao, G. C. (2009). Nuclear behavior in the life cycle of Melampsora larici-populina Kleb. J. Food. Agric. Environ. 7, 791-794.
Yu, Z. D., Zheng, W., Yu, D., Peng, S. B., and Cao, Z. M. (2017). Half-reserve mitosis of sibling nuclei in Gymnosporangium asiaticum. Int. J. Agric. Biol. 19, 1025-1030. doi: 10.17957/IJAB/15.0378

Zakharova, K., Tesei, D., Marzban, G., Dijksterhuis, J., Wyatt, T., and Sterflinger, K. (2012). Microcolonial fungi on rocks: a life in constant drought? Mycopathologia 175, 537-547. doi: 10.1007/s11046-012-9592-1

Zhang, Y., Wei, J., Qi, Y., Li, J. Y., Amin, R., and Yang, W. X. (2020). Predicating the effector proteins secreted by Puccinia triticina through transcriptomic analysis and multiple prediction approaches. Front. Microbiol. 11:538032. doi: $10.3389 /$ fmicb. 2020.538032

Zhao, H., Lv, M., Liu, Z., Zhang, M., Wang, Y., and Ju, X. (2020). High-yield oleaginous fungi and high-value microbial lipid resources from Mucoromycota. BioEnergy Res. doi: 10.1007/s12155-020-1 0219-3

Zheng, W., Newcombe, G., Hu, D., Cao, Z. M., Yu, Z. D., and Peng, Z. J. (2019). The first record of a North American poplar leaf rust fungus, Melampsora medusae, in China. Forests 10:182. doi: 10.3390/f100 20182

Conflict of Interest: The authors declare that the research was conducted in the absence of any commercial or financial relationships that could be construed as a potential conflict of interest.

Copyright $\odot 2021$ Zheng, Peng, Peng, Yu and Cao. This is an open-access article distributed under the terms of the Creative Commons Attribution License (CC BY). The use, distribution or reproduction in other forums is permitted, provided the original author(s) and the copyright owner(s) are credited and that the original publication in this journal is cited, in accordance with accepted academic practice. No use, distribution or reproduction is permitted which does not comply with these terms. 